\title{
Metal-Catalyzed and Metal-Mediated Approaches to the Synthesis and Functionalization of Tetramic Acids
}

\section{Dimitris Matiadis [}

Laboratory of Organic Chemistry, School of Chemical Engineering, National Technical University of Athens, Zografou Campus, 15773 Athens, Greece; dmatiadis@gmail.com; Tel.: +30-210-772-3259

Received: 27 November 2018; Accepted: 27 December 2018; Published: 7 January 2019

\begin{abstract}
The heterocyclic ring of tetramic acids is found in naturally occurred biologically active products isolated from fungi, bacteria, molds, and sponges. Thus, these molecules have attracted significant attention as synthetic targets, and various synthetic paths have been developed. Over recent years, a growing number of catalytic approaches toward functionalized products have been established in order to overcome the limitations of the conventional methods. The present review describes the strategies for the metal-catalyzed and metal-promoted synthesis and further derivatization of tetramic acids, with emphasis on recent examples from the literature.
\end{abstract}

Keywords: tetramic acids; nitrogen heterocycles; lactams; cyclization; bioactive compounds; natural products

\section{Introduction}

Natural and synthetic products incorporating the tetramic acid nucleus (pyrrolidine-2,4-dione) [1,2] have been identified as potent antibacterial [3-5], antifungal [6], antiviral [7], and anticancer agents [8]. In addition, these molecules exhibit agricultural bioactivities, such as being fungicidal [9-11], herbicidal [12,13] and nematicidal [14]. Reutericyclin, tenuazonic acid, streptolydigin, and equisetin are representative examples of biologically active natural products, whereas the most well-known commercial product is the insecticidal spirocyclic tetramic acid spirotetramat [15] (Figure 1).
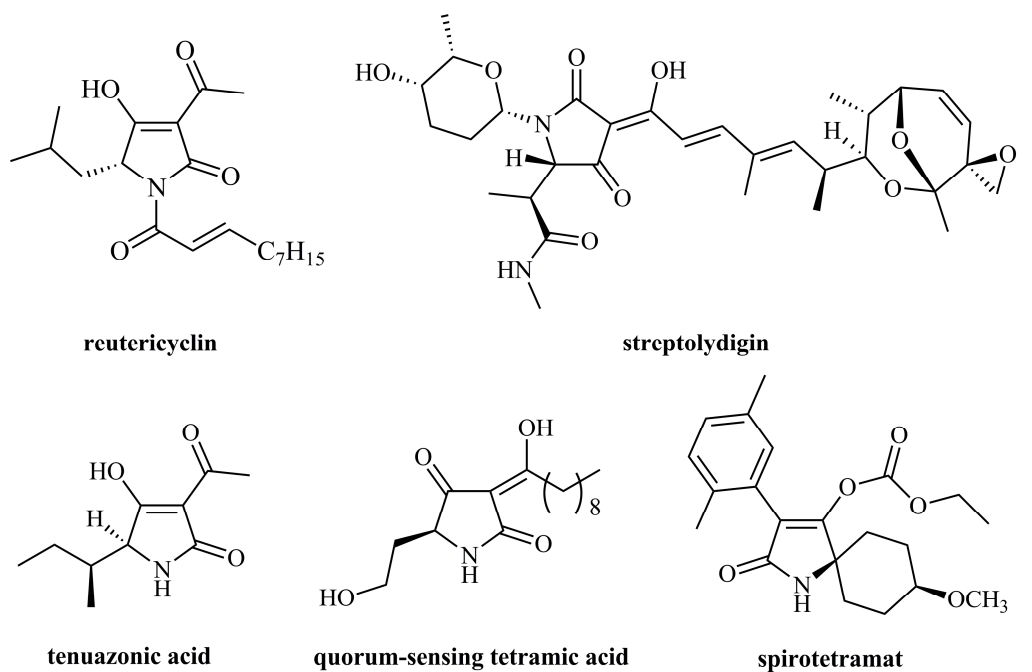

Figure 1. Examples of antimicrobial natural products incorporating the tetramic acid ring and the agricultural commercial available product spirotetramat. 
Tetramic acids are five-membered heterocycles containing the $\beta$-dicarbonyl system and, in the case of 3-acyl derivatives, the $\beta, \beta^{\prime}$-tricarbonyl system. They can be functionalized at position 3 and at position 5 of the ring. Sometimes, they exist as tetramates, having a $4-O$-substituted ether group. Particularly, the 3-acyltetramic acids, which are the most commonly found in natural products, exist as a mixture of tautomers (Scheme 1) [16]. The tautomerism appear in four detectable forms, more specifically, in two couples of fast-converting internal tautomers $(\mathbf{a} / \mathbf{b}$ and $\mathbf{c} / \mathbf{d})$. The conversion of the external tautomers is slower, making them detectable by NMR spectroscopy [17,18]. Factors such as the solvent, substituents, and temperature influence the ratio of the $\mathbf{a} / \mathbf{b} / \mathbf{c} / \mathbf{d}$.

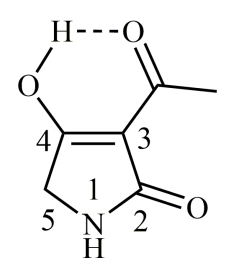

a<smiles>CC(=O)C1=C(O[IH])NCC1=O</smiles><smiles></smiles>

b

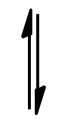<smiles></smiles>

Scheme 1. Tautomeric forms of 3-acetyl tetramic acids.

Tetramic acids possessing a 3-acyl group have the ability to chelate divalent or trivalent metal ions (Figure 2) $[19,20]$. Metal chelation by tetramic acid nucleus seems to be important for transport across membranes in biological tissues [2]. Janda et al. [21], in a great research article that boosted the synthetic interest in tetramic acids during the last decade, reported a novel tetramic acid degradation product from the quorum-sensing $\mathrm{N}$-acetyl homoserine lactone as a potent antibacterial agent and its complex with Fe(III). Schobert et al. [22] prepared complexes of natural melophlins A and C with $\mathrm{Mg}$ (II), Zn(II), $\mathrm{Ga}(\mathrm{III}), \mathrm{La}(\mathrm{III})$, and $\mathrm{Ru}(\mathrm{II})$, and found that the lanthanum and ruthenium complexes exhibit enhanced cytotoxic activities. Some of the tetramic acid-copper(II) complexes have shown higher antimicrobial activity than their parent compounds [23]. Markopoulou et al. have reported many synthetic and structural studies on tetramic acid complexes [24-26]. Recently, we found that the cadmium(II) complex of the $\mathrm{N}$-acetyl-3-acetyl-5-benzylidenetetramic acid inhibits most of the tested bacterial and fungal strains more effectively than the ligand, and it is particularly potent against Cryptococcus neoformans $(\mathrm{MIC}=8 \mu \mathrm{g} / \mathrm{mL}$ ) [27]. Apart from the above, a number of platinum or palladium containing 3-acyl tetramic acids with potential antitumor activities have been reported [28-30].

Noteworthy, Hosseini et al. have prepared $\mathrm{N}$-tetramic acid dipeptide analogues (Figure 3; Part A) [31], 3-amino-pyrrolidinone dipeptides [32], and tripeptides [33] that contributed to the research of peptidomimetics bearing tetramate analogues [34,35]. More recently, Lee et al. prepared ampicillin, cephalosporin, cephamycin, and other $\beta$-lactam-tetramic acid hybrids, and evaluated their antimicrobial activity (Figure 3; Part B) [36,37]. 


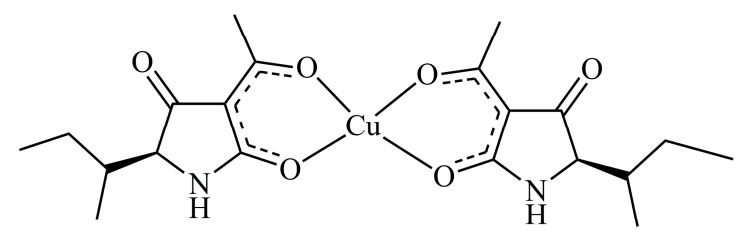

tenuazonic acid-Cu(II) complex

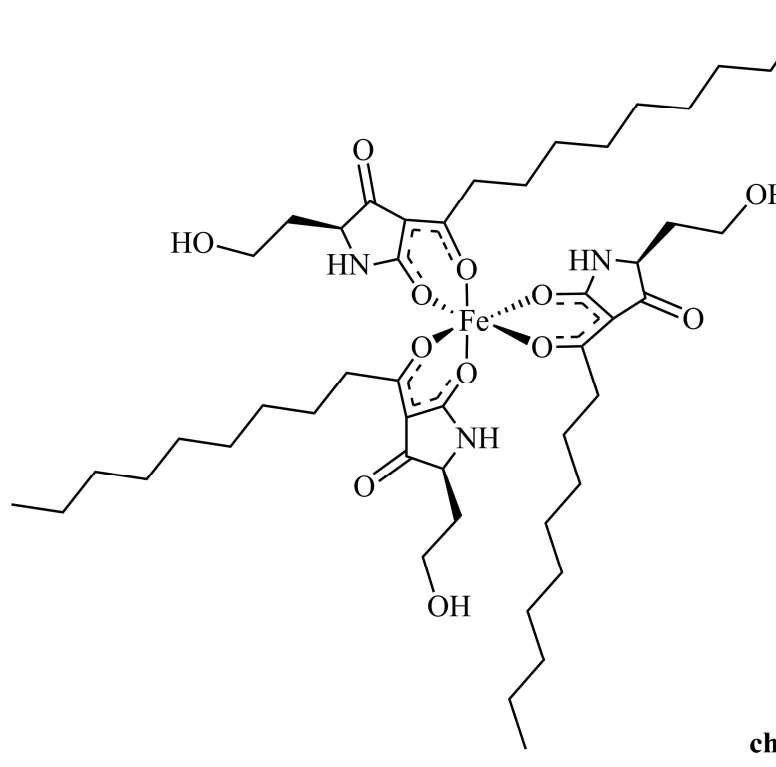

chlorido $\left(\eta^{6}-p\right.$-cymene)(melophlinato C)ruthenium(II)

quorum sensing tetramic acid-Fe(III) complex

Figure 2. Tetramic acid metal complexes with divalent or trivalent ions.

Even though tetramic acid was firstly synthesized in 1972 [38], preparations of 3-acetyl and other substituted tetramic acids have been available since the middle of 20th century [39]. Over the years, numerous papers have improved the established methodologies in terms of yield, purity, enantiopurity, and functionalization. Given the products' great biological activities, more and more functionalized and complex molecules are needed. However, the conventional synthetic strategies, often require highly functionalized and difficult to prepare starting materials or high temperatures in alkaline conditions. As the development of improved strategies toward these five-membered heterocycles is still in demand, a number of catalytic approaches have been developed as a tool to overcome the limitations of the traditional methods.

In this review, after an overview of the well-established conventional methodologies, we will present the catalytic protocols for the synthesis of tetramic acids and their analogues in a critical way one by one, mentioning the advantages and the limitations of each method. Moreover, the methodologies involving the use of a catalyst toward the further functionalization of the ring will be reported. 
A<smiles>CCOC1=CC(=O)N(C(=O)[C@H](N)Cc2ccccc2)C1C</smiles>

$O=\int_{\cdots \cdot R^{2}}^{R^{3}}$<smiles>[R]C1NC(=O)C[C@@H]1N</smiles>

$\mathrm{R}^{1}=\mathrm{Me}, \mathrm{i}-\mathrm{Pr}, \mathrm{i}-\mathrm{Bu}, \mathrm{CH}_{2}-\mathrm{c}-\mathrm{Hex}$

$\mathrm{R}^{2}=\mathrm{Me}, \mathrm{i}-\mathrm{Pr}, \mathrm{i}-\mathrm{Bu}$

$\mathrm{R}^{3}=\mathrm{OMe}, \mathrm{Ot}-\mathrm{Bu}, \mathrm{NH}_{2}$

tetramic acid analogues dipeptides

B<smiles>CC(C)CC1NC(=O)C(C(=O)NNC(=O)N[C@@H](C(=O)N[C@H]2C(=O)N3[C@@H](C(=O)O)C(C)(C)S[C@H]23)c2ccccc2)=C1O</smiles>

ampicillin-tetramic acid hybrid<smiles>CO[C@]1(NC(=O)CCCC(=O)C2=C(O)[C@@H](CCCNC(=N)N)NC2=O)C(=O)N2C(C(=O)O)C(CSc3nnnn3C)=CS[C@]21C</smiles>

cephamycin-tetramic acid hybrid

Figure 3. Representative examples of tetramate and tetramic acid analogues dipeptides (A) and $\beta$-lactam-tetramic acid hybrids (B).

\section{Conventional Synthetic Methods}

Until now, over 300 research articles have been published concerning the synthesis of tetramic acids. Up to 2008, this topic has been covered extensively by reviews on the chemistry, synthesis and biosynthesis of tetramic acids $[2,40,41]$. Since then, most of the synthetic papers involve modifications, further optimization on novel derivatives, and some sophisticated novel methods, some of which are catalytic.

Before we overview the methodologies for the preparation of the most important 3-acyl and 3-alkoxycarbonyl tetramic acids, we will briefly mention the synthesis of 3-unsubstituted tetramic acid. The tetramic acid was prepared decades after the 3-substituted analogues [38]. In fact, it derived from decarboxylation of the 3-ethoxycarbonyltetramic acid. Earlier approaches [42,43] were proven to lead to the isomeric 2-iminotetronic acid. In most circumstances, the 3-unsubstituted tetramic acid is used as a starting material toward 3-acylated derivatives [44-47]. 


\subsection{Lacey-Dieckmann Cyclization}

In 1954, Lacey published a two-step synthetic route to 3-acyltetramic acids 1 starting from $\alpha$-aminoesters 2 and diketene 3 (Scheme 2; Part A) [39]. This method is similar to the biosynthesis of these molecules. Lacey's strategy is flexible, and can be used in the preparation of many 3-acyltetramic acid derivatives. It has been used in a plethora of syntheses of compounds, even natural products [48]. Many modifications of this method have been published, the most important being the ones by $i$. Isowa and Ohta [49], in which an ethoxycarbonylacetyl chloride was used instead of the diketene; ii. Mulholland et al. [38], which used malonic ester chlorides; iii. Boeckmann [50] and Paquette [51] in ikarugamycin synthesis; and iv. Schlessinger via activated phosphonate intermediates [52,53]. Recently, the latter method was applied in the total synthesis of macrocidin A [54] and cylindramine A [55]. Lacey's method has been adapted successfully in solid-phase synthesis as well [56] (Scheme 2; Part B).<smiles>[R]C(N)C(=O)OCC</smiles>

2

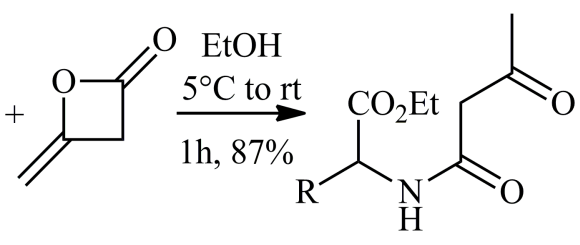

3<smiles>[R]C1NC(=O)/C(=C(/C)O)C1=O</smiles>

1

B<smiles>[R]CN1C(=O)C(C(=O)OCC)=C(O)C1[R]</smiles>

C

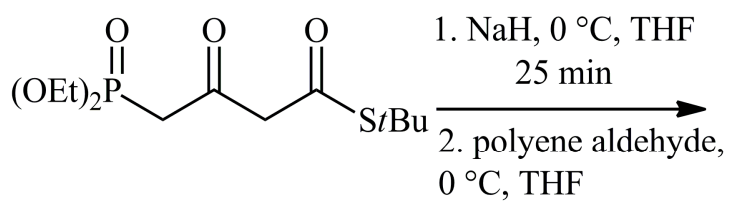<smiles>C/C=C/C(C)=C/C(C)=O</smiles>

(75\%)

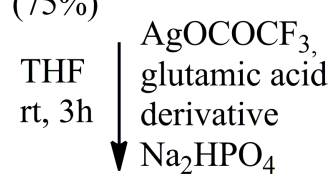<smiles>CC(C)=CC(O)=C1C(=O)[C@H](CCC(=O)O)N(C)C1=O</smiles>

1. $t \mathrm{BuOK}, t \mathrm{BuOH}$ rt, $30 \mathrm{~min}, 62 \%$

2. $\mathrm{HCOOH}$ rt, 1h, 76\% $t \mathrm{BuO}_{2} \mathrm{C}$

(74\%)

Scheme 2. Lacey's method with diketene 3 (A); solid-phase adaptation of Lacey's method (B); and Ley's enantioselective synthesis of Fuligorubin A 4 (C).

Partial racemization of the C-5 of the tetramic ring 1 can occur, since the hydrogen atoms on this carbon are acidic, and they are detached by the strong media used for the cyclization. Moreover, the synthesis of $\mathrm{N}$-acyl tetramic acids may require an additional step due to deprotection of the nitrogen from the sodium ethoxide. However, some great enantioselective syntheses exist, 
such as the synthesis of Fuligorubin A 4 by Ley (Scheme 2; Part C) $[57,58]$ and the synthesis of 3-polyenoyltetramic acids by Jones [59]. The key modification was the use of a milder base (TBAF or $t \mathrm{BuOK})$ for a short time.

\subsection{From Meldrum's Acid}

According to Jouin's method [60] a C-acylation reaction between the appropriate $\alpha$-aminoacid 5 and Meldrum's acid $\mathbf{6}$ using ICPF (isopropenyl chloroformate) as the acylating agent and DMAP (4-(dimethylamino)pyridine) as the catalyst, gives 3-unsubstituted tetramic acids 7 in two steps (Scheme 3; Part A). This protocol is ideal for the synthesis of these tetramic acids, due to the relatively mild conditions (neutral $\mathrm{pH}$ and refluxing the intermediate products in acetonitrile or ethyl acetate for 15-30 $\mathrm{min}$ ). The yields are very high (up to $94 \%$ for the $L$-phenylalanine derivative), and the reaction proceeds without racemization. The scope of this method is limited to 3-unsubstituted compounds. A convenient alternative to ICPF is the incorporation of CDI (1,1'-carbonyldiimidazole) as the acylating agent (Scheme 3; Part B) [61]. A slightly modified version of this route has found application in the synthesis of reutericyclin analogues [62]. Its adaptation in solid-phase synthesis has been reported in 2003 by Huang et al. (Scheme 3; Part C) [63].<smiles>[R]C(NC(=O)O)C(=O)O</smiles>

5<smiles>CC1(C)OC(=O)CC(=O)O1</smiles>

6<smiles>[R]C(NCCC)C(O)=C1C(=O)OC(C)(C)OC1=O</smiles>

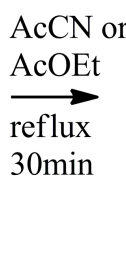<smiles></smiles>

B<smiles>[R]NCC(=O)O</smiles><smiles>CC1(C)OC(=O)CC(=O)O1</smiles>

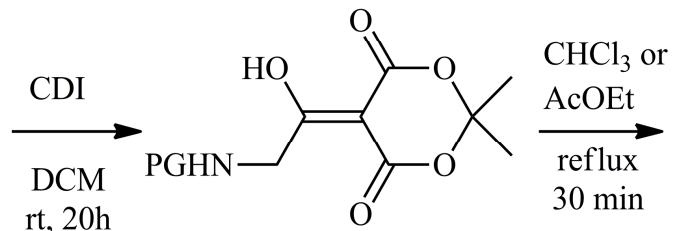

$(88-93 \%)$

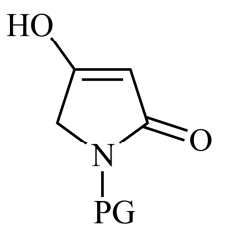

$(75-100 \%)$

$\mathrm{X}=-\mathrm{COPh}, \mathrm{Boc},-\mathrm{COMe},-\mathrm{COOMe}, \mathrm{Z},-\mathrm{COOEt}$

C

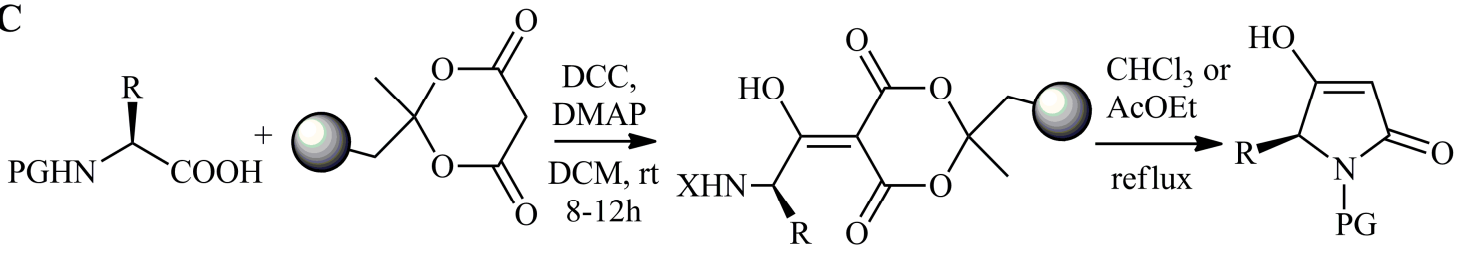

$(67-92 \%)$

Scheme 3. Jouin's method (A); reaction with CDI as acylating reagent (B); and the method adaptation in solid-phase synthesis by Huang et al. (C). 


\subsection{From $\beta$-Ketoesters or Diesters of Malonic Acid (Active Methylene Compounds)}

The first synthesis of tetramic acid using an active methylene compound (dimethyl malonate), which after deprotonation reacted with the activated carbonyl of the protected $\alpha$-amino acid, is attributed to Gabriel back in 1913 [64,65]. After the above C-acylation reaction, the intermediate ester cyclizes using concentrated sulfuric acid to 3-ethoxycarbonyl tetramic acid.

From early 1980s, Markopoulou et al. have developed a novel synthetic protocol, which affords functionalized tetramic acids $\mathbf{8}$ in high yields and purity without racemization. The key step of this method and its variations is a $\mathrm{C}$-acylation reaction between activated and protected $\alpha$-amino acid 9 and the appropriate active methylene compound 10. In the next step, the intermediate $\gamma$-amino ester or diester 11, which in many cases can be isolated, cyclizes under mild acid or basic conditions (e.g., 10\% hydrochloric acid, or $2 \mathrm{~N} \mathrm{NaOH}$ ) (Scheme 4; Part A). This methodology started with the use of $p$-nitrophenyl esters [66-68], but soon this acylating agent was replaced by the $N$-hydroxysuccinimide (Scheme 4; Part A) [69-72] and the 1-hydroxybenzotriazole (HOBt) 12 (Scheme 4; Part B) [73], which are able to give cleaner and enantiopure products (up to 99\% ee by chiral HPLC). The carbon-3 can be functionalized by acylation or condensation reaction [74], after decarboxylation in aqueous AcOEt under reflux of the 3-alkoxycarbonyl products.<smiles>[R]C(N)C(=O)OC(=O)Oc1ccc([N+](=O)[O-])cc1</smiles>

Scheme 4. Examples of Markopoulou group method toward 5-hydroxymethyl tetramic acid 8 using succinimide ester $\mathbf{9}$ (A); functionalized tetramic acids with HOBt 12 as acylating agent (B) and the protocol adaptation to solid-phase synthesis (C).

This protocol has been adapted successfully in the solid-phase synthesis of tetramic acids $\mathbf{1 3}$ using a p-nitrophenyl carbonate linker on Wang resin 14 (Scheme 4; Part C) [75]. 


\subsection{From Phosphorus Ylide $\mathrm{Ph}_{3} \mathrm{PCCO}$}

In 2004 and 2005, Schobert et al. reported the solid-phase syntheses of 3-acyltetramic acids of the tenuazonic [76] and melophlin family 15 (Scheme 5; Part A) [77], using immobilized (triphenylphosphoranylidene)ketene $\mathbf{1 6}\left(\mathrm{Ph}_{3} \mathrm{PCCO}\right)$ under mild conditions [78]. This ylide is involved in a Wittig-type cyclization reaction. The synthetic protocol is an adaptation of the same author's method toward tetronic acids [79].

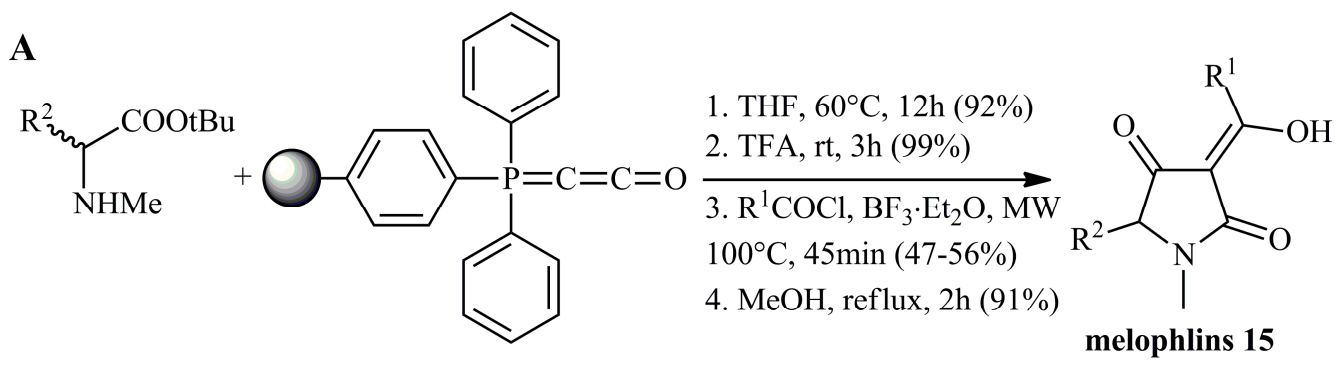

B

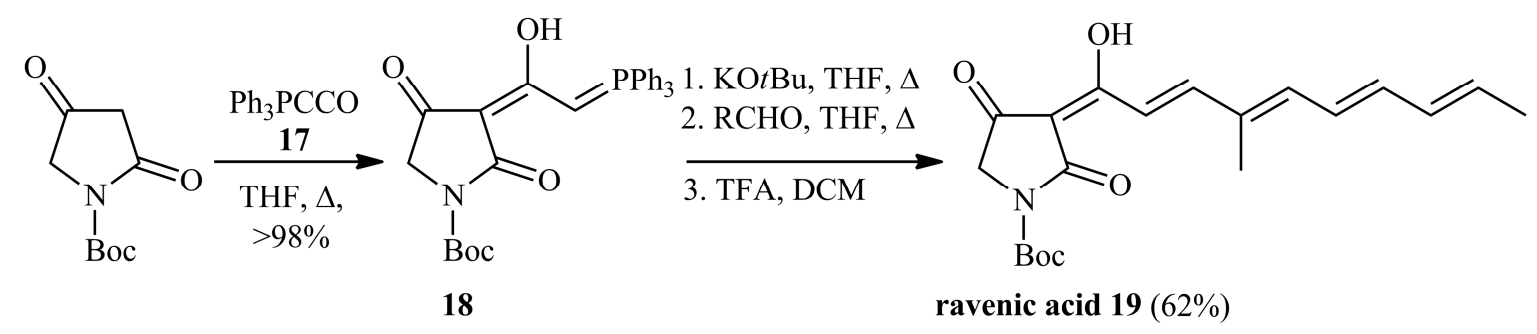<smiles></smiles>

Scheme 5. Solid phase synthesis of tetramic acids 15 with immobilized $\mathrm{Ph}_{3} \mathrm{PCCO} 16$ (A) and synthesis of ravenic acid 19 via selective 3-acylation of 3,5-unsubstituted tetramic acid (B).

Earlier, the synthesis of tetramates (and tetronates/thiotetronates) [80] incorporating the ylide $\mathrm{Ph}_{3}$ PCCO 17 was published following the first paper on this methodology on tetronates in 1995 [81]. As reported by the same group, since tetramic and tetronic acids have acidic hydrogens at C-3, they can react with the same ylide $\mathbf{1 7}$ to give the corresponding 3-(triphenylphosphoranylidene) acetyl derivatives 18 [82], which were used toward the synthesis of ravenic acid 19 in 2010 (Scheme 5; Part B) [47].

This protocol has been applied in the total synthesis of many tetramic natural products such as $5 R$-reutericyclin [83], penicillenols $B_{1}, B_{2}$ [84], $C_{1}$, and an isomer of methiosetin [85].

\subsection{Involving Activated Cyclic Starting Materials or Intermediates}

DeShong et al. developed a method based in Lacey's protocol, according to which the alkylation of a substituted isoxazole $\mathbf{2 0}$ followed by fragmentation of the resulting isoxazolium salt $\mathbf{2 1}$ leads to a $\beta$-ketoamide 22 [86,87]. Next, this intermediate undergoes base-catalyzed cyclization under Lacey's conditions to afford 3-acyltetramic acid 23 (Scheme 6; Part A).

Markopoulou et al. have reported two protocols involving cyclic starting materials for activation and/or protection. The first involved (S)-N-acetylaspartic acid anhydride [88]. Optically active 3-acyl-5-carboxymethyl tetramic acids were prepared with this route. An interesting feature of this study is the incorporation of 3-alkyl and 3-aryl substituents using LDA at $-78^{\circ} \mathrm{C}$, without racemization. A similar starting material, O-protected hydroxyl succinic anhydride (malic acid anhydride), 
has been used from the same group [89] for the synthesis of chiral tetronic acids. In the second, 2-methyl-4-benzylidene-5(4H)-oxazolone $\mathbf{2 4}$ was found to serve successfully as both a protected and an activated $\alpha$-amino acid. Therefore, the desired 5-benzylidene tetramic acid 25 was prepared in just one step (Scheme 6; Part B), without the removal of the $N$-acetyl group, which is considered crucial for the biological activities and the natural product synthesis [26]. Stachel has prepared a library of $N$-benzoyl or $\mathrm{N}$-unsubstituted 5-arylidenetetramic acids [90] starting from a similar 2-phenyl oxazolone.<smiles>[R]c1ccn(C([R2])C)c1C(=O)OCC</smiles>

20

B<smiles>CC1=N/C(=C\c2ccccc2)C(=O)O1</smiles>

24

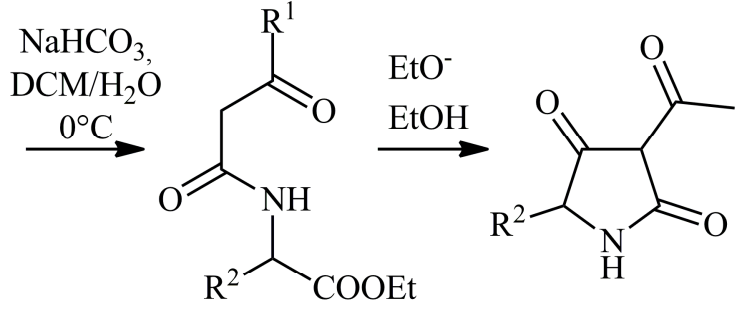

22
23

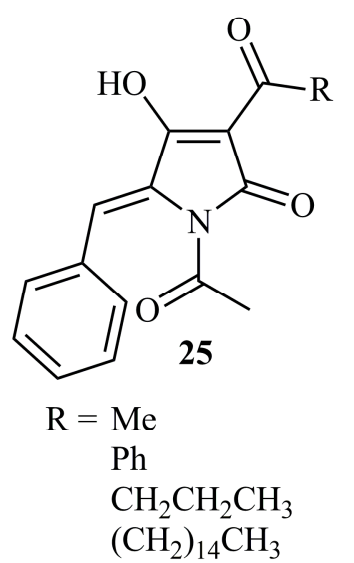

Scheme 6. Examples of DeShong's method (A) and our published method toward benzylidene tetramic acids 25 (B).

Martinez used protected (Fmoc, Boc or Z) urethane- $N$-carboxyanhydride $\mathbf{2 6}$ to prepare $\mathrm{N}$-protected 3-unsubstituted chiral tetramic acid 27 under mild conditions (Scheme 7; Part A) [91]. This synthesis is an interesting modification of Jouin's method. Two synthetic methods developed by Jones are using cyclic starting materials or active intermediates as precursors to 3-acyltetramic acids. The first involves the conversion of a pyrone ( $\delta$-lactone) to 3-acyltetramic acid [92], and the second is a cycloaddition approach via active isoxazolecarboxylic esters [93].

One of the most interesting and well-established methods for the preparation of chiral tetramic acids is Moloney's method. Regioselective Dieckmann cyclization using an $N$-acyloxazolidine 28 derived from serine [94,95], and later $\alpha$-methyl serine [96] and threonine $\mathbf{2 9}$ (Scheme 7; Part B) [97,98] gives functionalized monocyclic $\mathbf{3 0}$ or bicyclic tetramic acid $\mathbf{3 1}$ in high yield and enantioselectivity. Moloney's group has studied in detail the antibacterial activity of many modified tetramic acid libraries using this method [4,99-101]. 
A<smiles>[R]C1C(=O)OC(=O)N1[R17](=O)[O-]</smiles>

26<smiles>CCCOC(=O)C(C)=C1C(=O)OC(C)(C)OC1=O</smiles><smiles>[R]C1C(O)=CC(=O)N1[R]</smiles>

$27(60-87 \%)$

B<smiles>COC(=O)[C@@H](N)[C@H](C)O</smiles>

29 reflux, 16-20h

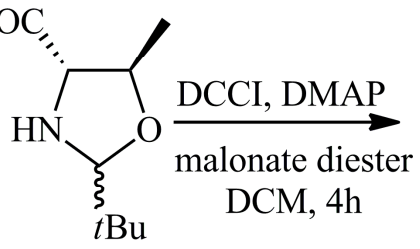

28 (74\%)<smiles>[R]C(C(=O)OCC)C(=O)N1[C@H](CC(C)C)O[C@H](C)[C@H]1C(=O)OCC</smiles>

(73-87\%)

1. $t \mathrm{BuOK} / \mathrm{t} \mathrm{BuOH}$, reflux 3-8h 2. $\mathrm{NaOH}$, reflux, $5 \mathrm{~h}$<smiles>[R]C1=C(O)[C@@H]([C@H](C)O)NC1=O</smiles>

$30(82 \%)$<smiles>[R]C1=C(O)[C@H]2[C@@H](C)O[C@@H]([13CH3])N2C1=O</smiles>

31

Scheme 7. Martinez modification to Jouin's method (A) and synthesis of chiral tetramic acids 30, 31 by Moloney, starting from $L$-threonine methyl ester 29 (B).

\section{Metal-Based Catalytic and Metal-Mediated Syntheses and Functionalizations of Tetramic Acids}

\subsection{Preparation of Tetramic Acids}

\subsubsection{Silver-Catalyzed $\mathrm{CO}_{2}$ Incorporation to Propargylic Amines}

A novel methodology toward tetramic acids has been developed by Yamada et al. involving silver-catalyzed carbon dioxide incorporation into propargylic amine $\mathbf{3 2}$ forming a substituted oxazolidinone 33 [102]. This intermediate undergoes an intramolecular rearrangement under mild conditions (DBU-1,8-diazabicyclo[5.4.0]undec-7-ene, $60{ }^{\circ} \mathrm{C}$ ) to yield the corresponding tetramic acid 34 (Scheme 8). The group reported a one-pot reaction as well, to solve the problem of the 5 -unsubstituted tetramic acid, which was not able to be prepared in the initial conditions. So far, the reported compounds are limited to 3-aryl (except one unsubstituted derivative), and most of them are 5-disubstituted with the same substituents or 5-hexyl. In the case of 5-monosubstituted (5-ethyl or 5-phenyl) compounds, they appear to be racemic. The authors' hypothesis for the reaction mechanism involved the formation of a cyclic intermediate through silver catalyzed alkyne activation, followed by intramolecular cyclization triggered by deprotonation of the amide from the base (DBU). 


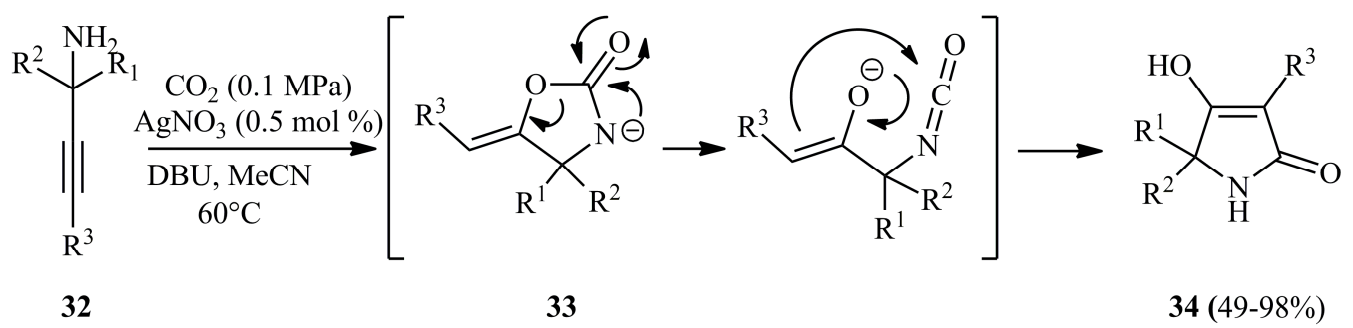

Scheme 8. Yamada's silver-catalyzed synthesis of tetramic acids 34 via intramolecular rearrangement.

This method is presented as an application of that previously reported by the same group transformations using similar starting materials for the $\mathrm{CO}_{2}$ incorporation. In one of them, the authors described the synthesis of benzoxazine-2-ones with the same silver catalytic system [103]. Yamada et al. have prepared as well, a number of biologically interesting 4-hydroxyquinolin-2(1H)-ones 35 under mild conditions in the presence of catalytic $\mathrm{AgNO}_{3}$ (Scheme 9; Part A). Isotopic labeling experiments revealed that the quinolinone contained the carbon dioxide atoms [104]. Earlier, in 2009, in the presence of silver acetate oxazolidinones were prepared under mild conditions without any base [105]. Since then, many heterocyclic compounds such as cyclic carbonate 36 (Scheme 9; Part B) [106] and numerous 2-oxazolidinone derivatives [107] have been prepared by a metal catalyzed reaction of $\mathrm{CO}_{2}$ with propargylic amine or alcohol 37 and even the metal-free synthesis of substituted oxazolones [108].

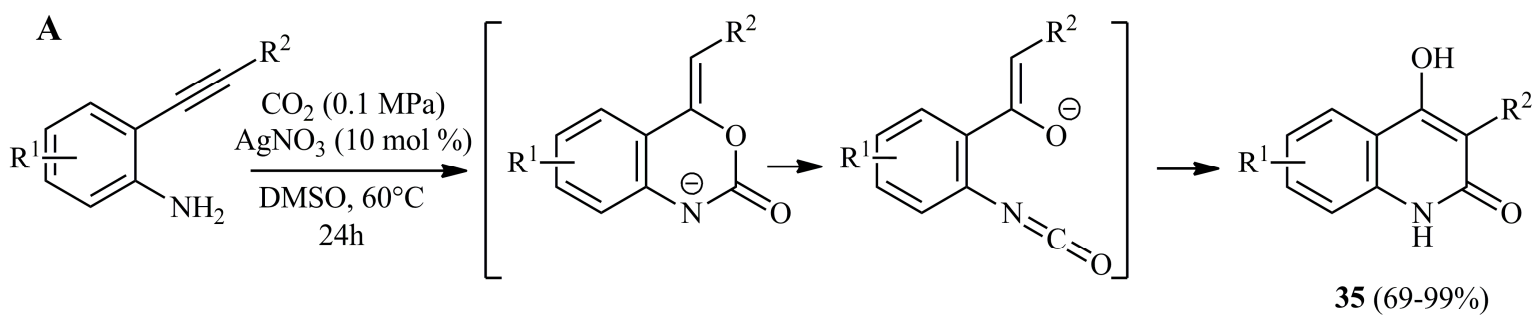

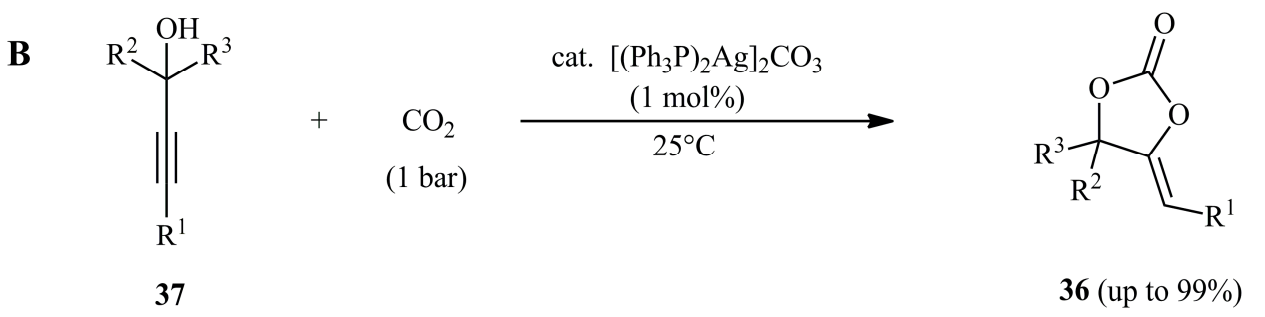

Scheme 9. Silver catalyzed $\mathrm{CO}_{2}$ incorporation reaction toward 4-hydroxyquinolin-2(1H)-ones 35 (A) and He's synthesis of cyclic carbonate 36 from propargylic alcohols 37 (B).

\subsection{2. $\mathrm{SmI}_{2}$-Mediated Cyclizations}

Recently, Huang and Py developed a method for the synthesis of chiral tetramic acids 38 involving $\mathrm{SmI}_{2}$-mediated reducting coupling via $\beta$-methylenyl- $\gamma$-amino esters 39 . This mild reducting agent was used to produce the above intermediate esters from nitrones or tert-butanesulfinyl imines $\mathbf{4 0}$ (Scheme 10; Part A). The esters 39 were cyclized to the corresponding $\beta$-methylenyl- $\gamma$-lactams 41 with zinc under ultrasound activation, or by acid hydrolysis $(\mathrm{HCl}$ in $\mathrm{MeOH})$. The produced lactams can be easily converted to tetramic acids $\mathbf{3 8}$ by ozonolysis (Scheme 10; Part B). The final tetramic acid $\mathbf{3 8}$ was found to be optically active, and its chirality was determined by comparison of the $\alpha_{\mathrm{D}}$ with literature data; however, no enantiomeric excess was reported [109]. 
The same year, Pettus et al. reported the synthesis of chiral 3-methyl tetramic acids $\mathbf{4 2}$ under mild conditions, using $\mathrm{SmI}_{2}$-mediated cyclization (Scheme 11). In the same work, the application of the protocol to the total synthesis of the cytotoxic 3-methyl tetramate natural product palau'imide was presented. The paper demonstrates the synthesis of seven derivatives with high yields and good to exceptional enantiomeric ratios (84:16 to >99:1, determined by HPLC) [110].

A<smiles>CC(C)/C=N/S(=O)CBr</smiles>

40<smiles>C=C=CC(=O)OCCCCCCCCC</smiles>

$\mathrm{THF},-40^{\circ} \mathrm{C}$<smiles>C=C(CC(=O)OCc1ccccc1)C(CCCCCC)NS([CH2-])=O</smiles>

39 (55-87\%)<smiles></smiles>

39<smiles>C=C1CC(=O)NC1C(C)C</smiles>

41 (77\%)

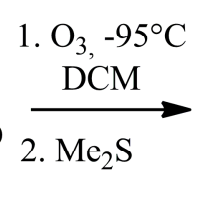<smiles>CC(C)[C@H]1NC(=O)CC1=O</smiles>

$38(60 \%)$

Scheme 10. $\mathrm{SmI}_{2}$-mediated reducing coupling to $\beta$-methylenyl- $\gamma$-amino ester $39(\mathbf{A})$ and synthesis of tetramic acid 38 after cyclization of the ester 39 and ozonolysis of the corresponding $\gamma$-lactam 41 (B).

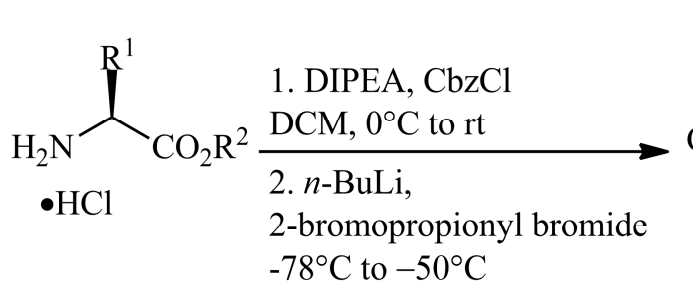
$-78^{\circ} \mathrm{C}$ to $-50^{\circ} \mathrm{C}$<smiles>[R]OC(=O)C([R])N(C(=O)[O-])C(=O)[C@H](C)Br</smiles>

(41-87\%)

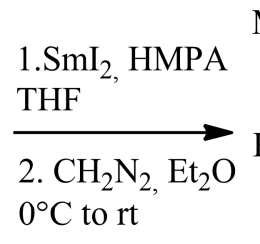
$0^{\circ} \mathrm{C}$ to rt<smiles>[R]C1C(OC)=C(C)C(=O)N1C(=O)O</smiles>

42 (63-84\%)

Scheme 11. Pettus' synthesis of 3-methyl tetramic acid 42 via $\mathrm{SmI}_{2}$-mediated cyclization.

Similarly to Py's method, intermediate lactams have previously been prepared by indium-catalyzed Conia-ene reactions [111], by the selective ring expansion of secondary methylenecyclopropyl amides using catalytic $\mathrm{MgI}_{2}$ at high dilution [112]. Pattenden's work on the radical cyclizations of propargyl bromoamides 43 [113] found application to the synthesis of lactams similar to tetramates [114], to the synthesis of $\gamma$-lactams [115], and ultimately to the synthesis of 3-methyl-5,5-disubstituted tetramic acids 44 via ozonolysis of the corresponding $\gamma$-lactam 45 (Scheme 12) [116]. These protocols involve the cyclization of the enantiopure $\alpha$-ethynyl substituted serine derivatives using $\mathrm{Bu}_{3} \mathrm{SnH}$ and AIBN (azobisisobutyronitrile).<smiles>C#C[C@@](COC(C)=O)(NC(=O)C(C)Br)C(C)=O</smiles>

43

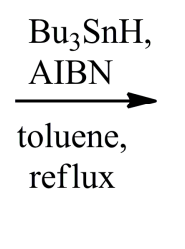<smiles>[C+]OC[C@@]1(C(C)=O)NC(=O)[C@@H](C)C1=C</smiles>

$45(60 \%)$

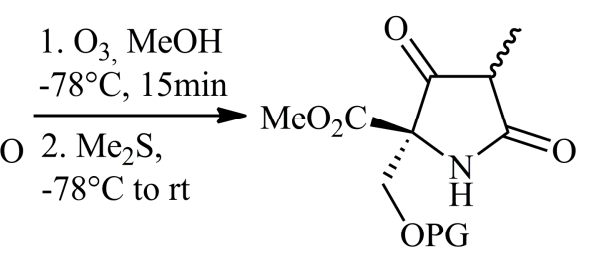

$44(75 \%)$

Scheme 12. Pattenden's radical approach to 3-methyl tetramic acids 44. 
Nevertheless, the samarium diiodide, which was first used in organic synthesis by Kagan et al. [117], has been used for the development of various transformations and cyclization reactions under mild conditions [118].

\subsubsection{Pd-Catalyzed Oxidative Aminocarbonylation of 2-Ynylamines}

An interesting novel synthesis of 4-dialkylamino-5,5-disubstituted- $\gamma$-lactam 46 by $\mathrm{PdI}_{2}$-catalyzed oxidative carbonylation of the appropriate 2-ynylamine 47 was reported in 2004 by Gabriele et al. [119]. The method is an expansion of the previously published method by the same group for similar $\gamma$-lactones [120]. The $\gamma$-lactams can easily be transformed to tetramic acid 48 by acid hydrolysis at room temperature. The reaction toward lactam 46 proceeds in one step. 2-Ynylamines are directly carbonylated using the appropriate amine in the presence of palladium diiodide and a mixture of $\mathrm{CO}$-air at $20 \mathrm{~atm}$ and at 25 to $100{ }^{\circ} \mathrm{C}$ (Scheme 13). The starting 2-ynylamines can easily be prepared from 2-yn-1-olacetates according to the literature method [121]. The derivatives presented in this publication are limited to 3-unsubstituted lactams with no reference to enantiomeric excess at C-5.

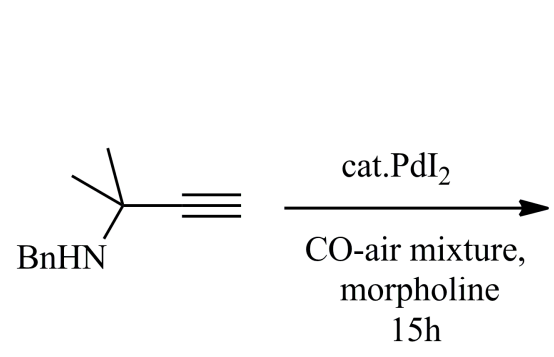

47

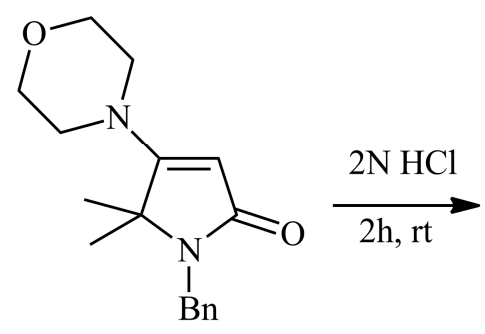

$46(65 \%)$<smiles>CC1(C)C(=O)CC(=O)N1Cc1ccccc1</smiles>

$48(99 \%)$

Scheme 13. Gabriele's Pd-catalyzed method to $\gamma$-lactam 46, which can easily be converted to tetramic acid 48.

\subsubsection{Lithium Telluride-Triggered Synthesis of Tetramic Acids}

An alternative approach to the synthesis of 3-unsubstituted, 3-methyl, and 3,3-dimethyl tetramic acid 49 and tetramates by Dieckmann cyclization promoted by $\mathrm{Li}_{2} \mathrm{Te}$ has been reported by Dittmer et al. (Scheme 14; Part A) [122]. The reaction undergoes in mild conditions with no strong base involved, thus reducing the formed side products. On the other side, racemization occurs with the addition of the silyl ether. The authors noticed that greater excess of the $t$-butyldiphenylsilyl chloride reagent increases the yield to be almost quantitative, but produces racemic products. In some cases, such as the 3,3-dimethyl $\mathbf{5 0}$ or the 3-unsubstituted derivative 51, the target molecule can be prepared without the addition of a base (Scheme 14; Part B, C). Schobert et al. applied this reaction to the synthesis of the natural product rigidiusculamide B using only 1.15 equivalents of the silyl reagent, reducing the racemization to a minimum of 6:1 (diastereomeric ratio) [123]. The lithium telluride reagent is prepared by known literature methods [124], as this reagent has been used in numerous syntheses of heterocycles [125-127]. In general, this less known reaction is a good alternative for the synthesis of 3-methyl tetramic acids, which are not readily produced from conventional methodologies. 
A<smiles>[R]C=C([O])N([R])C([R])C([R])=O</smiles><smiles>[R]C1C(=O)C([R1])([R])C(=O)N1[R]</smiles>

1. $\mathrm{Me}_{2} \mathrm{CBrCOBr}$,

B

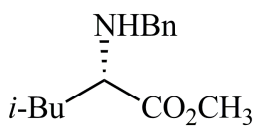

2,6-lutidine DCM, rt, $1 \mathrm{~h}(99 \%)$

2. $\mathrm{Li}_{2} \mathrm{Te}, \mathrm{THF}$

rt, $18 \mathrm{~h}(79 \%)$<smiles>CCCCN1C(=O)C(C)(C)C(=O)C1CC(C)C</smiles>

C<smiles>[R]C(NC(=O)OCC)C(=O)OC</smiles>

$$
\begin{gathered}
\underset{\mathrm{Na}_{2} \mathrm{Te}, 15 \text {-crown-5 }}{\mathrm{THF}} \\
\mathrm{rt}, 20-30 \mathrm{~min}(50-55 \%)
\end{gathered}
$$<smiles>[R]C1C(=O)CC(=O)N1[Y]</smiles>

Scheme 14. General protocol for the synthesis of tetramic acid 49 using lithium telluride (A); 3-disubstituted derivative $\mathbf{5 0}$ without the addition of base (B) and 3-unsubstituted tetramic acid 51 without base; but using crown ether and the similar sodium telluride (C).

\subsection{5. $\mathrm{ZrCl}_{4}$-Catalyzed Synthesis of $\beta$-Ketoamides}

$\beta$-Ketoamides are versatile intermediates in the synthesis of many heterocyclic compounds, for example lactams [128], isoquinolines [129], and naphthyridines [130]. Apparently, they are used for the synthesis of 3-acyltetramic acids via Dieckmann cyclization. However, in the established conventional methods, there is a limitation in the group that can be incorporated at C-3 of the ring. This problem has been solved to an extent by the catalytic or non-catalytic 3-acylation of 3-unsubstituted tetramic acids. Yet again, these methodologies are often unable to provide solutions to chemoselectively acylate a 3,5-unsubstituted tetramic acid at position C-3 of the heterocycle.

Yoshii et al. have developed a method for the $\mathrm{Zr}(\mathrm{IV})$ chloride-catalyzed $\mathrm{C}-\mathrm{H}$ insertion reaction of aldehyde 52 with the diazoacetamide of $\mathrm{N}$-protected glycinate 53 (Scheme 15). This protocol is compatible with the Dieckmann cyclization to afford the desired 3-acylated 5-unsubstituted tetramic acid 54. According to the literature, two equivalents of the catalyst are used, and the reaction is quite effective for sterically hindered aldehydes [131].

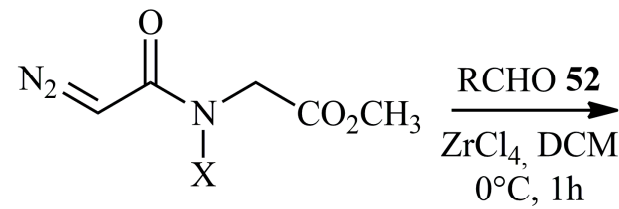

53<smiles>[R]C(=O)CC(=O)N([X])CC(C)=O</smiles>

$(53-79 \%)$

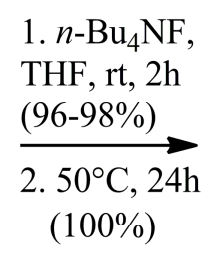

$(100 \%)$

54

Scheme 15. $\mathrm{ZrCl}_{4}$ catalyzed synthesis of $\beta$-acetamide 53 toward tetramic acid 54 with bulky 3-acyl groups. 


\subsubsection{CuI-Catalyzed Synthesis from $\beta$-Ketoesters}

An unexpected simple and practical one-step synthetic method toward 1-benzyloxycarbonyl-3, 5-disubstituted tetramic acid $\mathbf{5 5}$ has been reported recently by González-Muñiz et al. (Scheme 16; Part A) [132]. Studying the applications of the known CuI/L-proline catalytic system for coupling reactions of aryl halides with active methylene compounds to 2-aryl-1,3-dicarbonyl molecules [133], they developed and optimized a method for the synthesis of tetramic acid 55. Controlling the reaction conditions, it is possible to obtain the intermediate dicarbonyl derivative 56 (Scheme 16; Part B). Chiral HPLC experiments for the determination of the optical purity is reported only for the indole analogues, and indicate almost complete racemization.

A

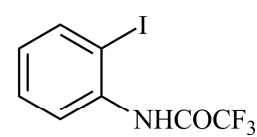<smiles>C1CCC1</smiles><smiles>[R]C(NC(=O)OCc1ccccc1)C(=O)CC(C)=O</smiles>

B<smiles>[R]C(NC(=O)OCc1ccccc1)=C(O)C(C(C)=O)=C1C=CC=CN1C(F)(F)F</smiles>

56

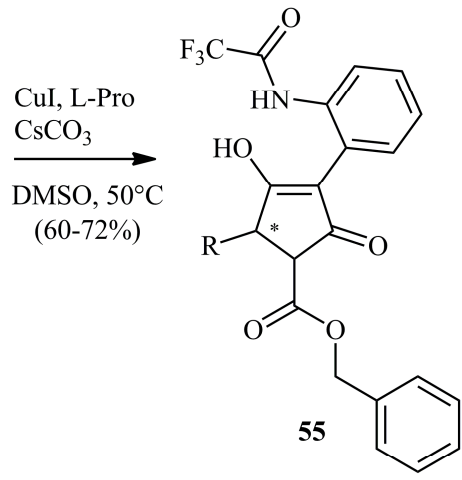

Scheme 16. CuI/L-Pro synthesis of tetramic acids 55 (A) and the structure of the dicarbonyl intermediate $56(\mathrm{~B})$.

\subsection{Transformations of Tetramic Acids}

\subsubsection{Pd-Catalyzed $\alpha$-Arylation of Tetramic Acids}

In 2009, Tanner et al. published an interesting research article [134] on the Pd-catalyzed $\alpha$-arylation of tetramic acids 57. The few methods described in the literature [94,135] until then were not general, and required the use of a strong base. Even though many existing methods of the $\alpha$-arylation of similar systems (1,3-dicarbonyl compounds) led to non-chiral products, the authors performed extended optimization of the reaction conditions, and they concluded to high yielded conversion under mild conditions for most of the substrate 58 with enantiomeric excess up to $97 \%$ (Scheme 17). Specifically, it was found that the ideal results can be obtained using $2 \% \operatorname{Pd}(\mathrm{OAc})_{2}, 4 \%$ of 2-di-tert-butylphosphino-2' $4^{\prime}, 6^{\prime}$-triisopropyl-1,1'-biphenyl as the phosphine ligand, and the weak inorganic base $\mathrm{K}_{3} \mathrm{PO}_{4}$. The reaction was held in THF at $80^{\circ} \mathrm{C}$ for one hour. Most of the substrate 58 that was tested gave identical results e.g., protected amines, nitro groups alcohols, ketones, ethers, esters, and others, except heterocycles and unprotected imines, which were found to be non-compatible. Meta-substituted and para-substituted aryl halides worked, whereas ortho-substituted compounds did not react due to steric hindrance. 


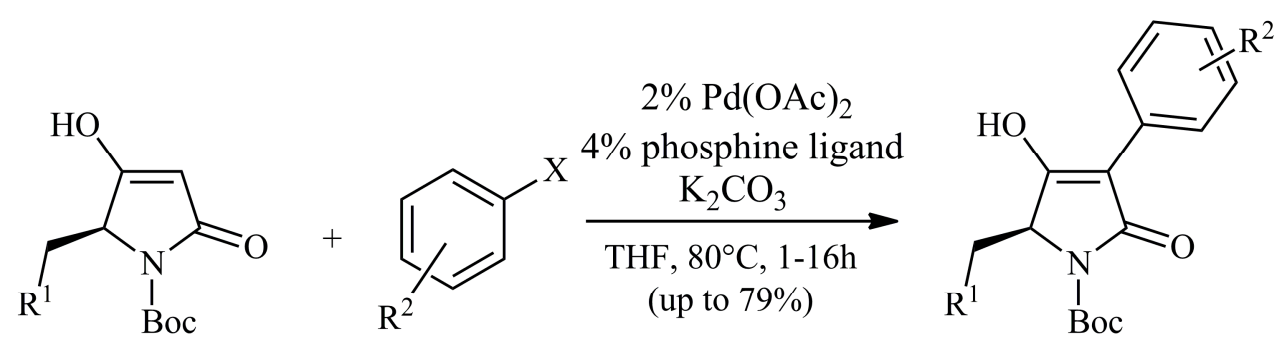

57

58

Scheme 17. $\mathrm{Pd}(\mathrm{OAc})_{2}$ catalyzed 3-arylation of tetramic acids $\mathbf{5 7 .}$

\subsubsection{Metal-Catalyzed 3-Acylation of Tetramic Acids}

One of the most common catalytic reactions on the tetramic acid ring is undoubtedly the Lewis acid acylation on C-3 with acyl chlorides. While boron trifluoride-diethyl ether has been used for acylations [136], titanium(IV) chloride is used universally in nitromethane or dichloromethane under mild heating (Scheme 18) [44,137].

$\mathbf{A}$

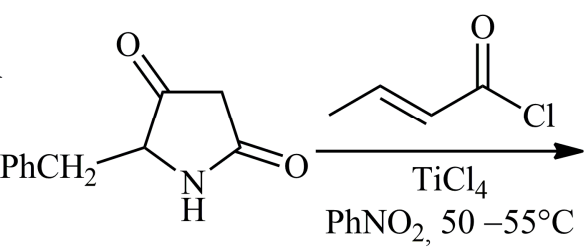<smiles>[R]C(=O)C1=C(O)C(Cc2ccccc2)NC1=O</smiles>

$(52 \%)$

B<smiles>CCCCCCCC=CC(=O)N1C(=O)CC(=O)C1CC(C)C</smiles>

$\mathrm{CH}_{3} \mathrm{COCl}$

$\mathrm{TiCl}_{4}, \mathrm{DCM}$

3 h, reflux<smiles>CCCCCCCCC=CC(=O)N1C(=O)C(C(C)=O)=C(O)C1CC(C)C</smiles>

racemic reutericyclin $(17 \%)$

Scheme 18. 3-Acylation reaction with titanium tetrachloride (A) and 3-acetylation in the final step of racemic reutericyclin total synthesis $(\mathbf{B})$.

\subsubsection{Chemoselective Ru-Catalyzed Hydrogenation of Exocyclic $\mathrm{C}=\mathrm{C}$ Bonds}

In 2011, Karaiskos et al. reported a pioneering method for the chemoselective catalytic hydrogenation of exocyclic double carbon bonds in 3,5-bisarylidene tetramic acid 59 [74]. According to this method, the exocyclic double carbon bonds are preferentially hydrogenated over other reducing functions (endocyclic C3-C4 double bond and carbonyls). Moreover, by carefully selecting the conditions, the reduction of the double bond at C-5 or both C-3 and C-5 is achievable. The chemoselectivity depends on the Ru complex ligands, substrate, solvent, and temperature. The reaction conditions were, as expected, harsher than those for the non-conjugated systems reported in the literature. Depending on the substrate, the yield of the hydrogenation process can reach up to $95 \%$ (Scheme 19). The variation of the applied hydrogen pressure is less effective compared to the temperature; however, higher pressure favors the formation of the more saturated molecule. 
<smiles>[R]c1ccc(/C=C2\NC(=O)/C(=C\c3ccc([R])cc3)C2=O)cc1</smiles>

59

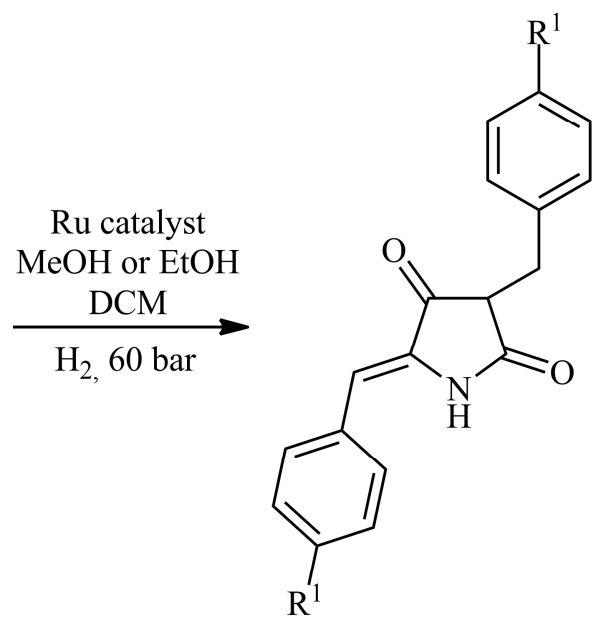

up to $95 \%$<smiles>[R]c1ccc(CC2NC(=O)C(Cc3ccc([R])cc3)C2=O)cc1</smiles>

up to $94 \%$

Scheme 19. Ru-catalyzed hydrogenation of 3,5-bisarylidene tetramic acid $59\left(\mathrm{R}^{1}=\mathrm{H}\right.$ or $\mathrm{OCH}_{3}, \mathrm{R}^{2}=\mathrm{H}$ or $\mathrm{CH}$ ).

$\mathrm{H}_{4} \mathrm{Ru}_{4}(\mathrm{CO})_{9}\left[\mu_{3}-(\mathrm{S})\right.$-BINAP] catalyst (Figure 4 ) developed by Tunik et al. [138] at a substrate to catalyst ratio of 120:1 to 700:1 was used.

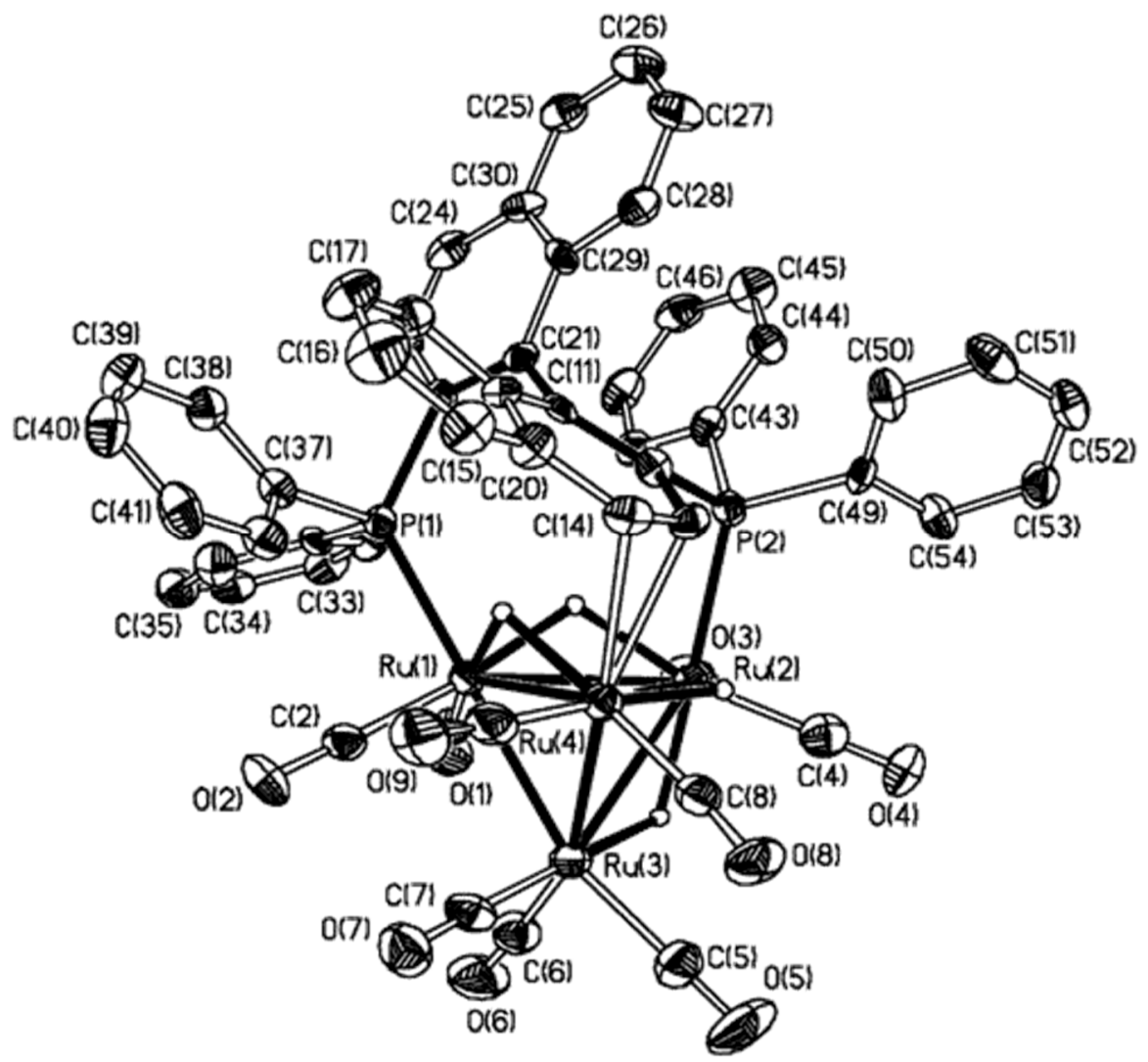

Figure 4. $\mathrm{H}_{4} \mathrm{Ru}_{4}(\mathrm{CO})_{9}\left[\mu_{3}-(S)\right.$-BINAP] catalyst. Adapted with permission from reference [139]. Copyright 2004 American Chemical Society.

\subsubsection{Rhodium-Catalyzed Transformations of Diazotetramic Acids}

An interesting method for diazotetramic acids thermolysis in the presence of dirhodium tetraacetate was reported by Stachel et al. $[139,140]$. In these works, enolic 3-alkoxytetramic acid 60 were prepared by the rhodium-catalyzed decomposition of diazotetramic acids 61 at $130{ }^{\circ} \mathrm{C}$ in 
the presence of tert-butanol 62 (Scheme 20; Part A). After deprotection, the corresponding 3-hydroxy tetramic acid 63 is formed, thus leading to the monoether 64 at C-4 of the ring or to the dietheric tetramic acid 65. Later, the same group applied this method for the incorporation of an aryl group at C-3 of the ring using anisole or benzene instead of alcohol in a sealed tube (Scheme 20; Part B) [141]. This protocol was first presented for the synthesis of similar maleimide derivatives [142].

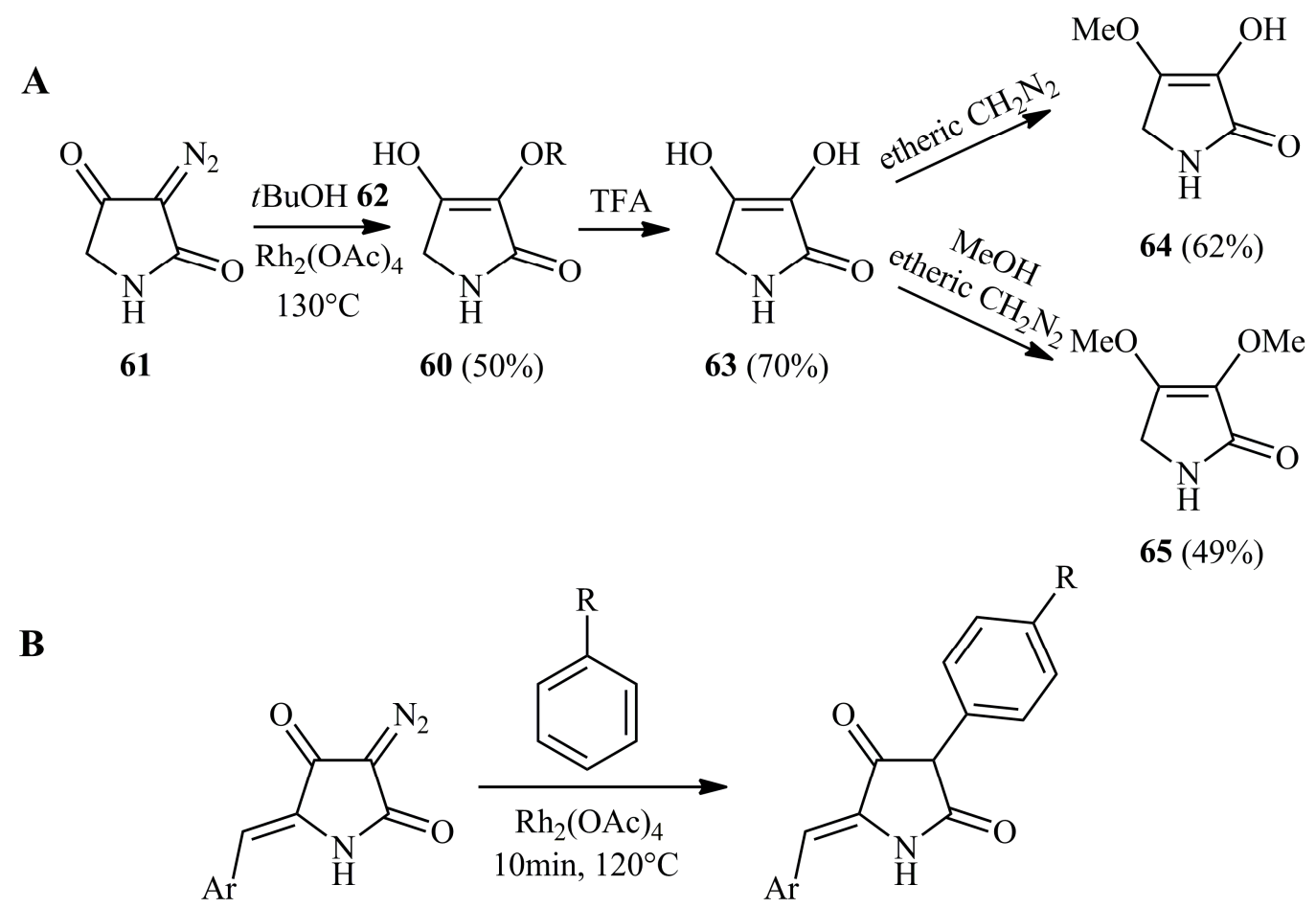

Scheme 20. Rhodium-catalyzed transformation of diazotetramic acid 61 to 3-alkoxytetramic acid 60 (A) and incorporation of an aryl group at C-3 of a 5-arylidene tetramic acid (B).

\subsubsection{Annulation Reactions}

Similar reaction conditions were used by Novikov et al. using $2 \mathrm{H}$-azirine instead of alcohol or benzene in 1,2-dichloroethane, but no products were detected. Instead, when the authors replaced the rhodium catalyst with copper acetylacetonate, the hybrid pyrroline-1,2,3-triazole molecule 66 was produced (Scheme 21) [143]. The compound was formed from the addition of two azirine molecules 67 to the diazotetramic acid 68. It is noteworthy that various metals, such as $\mathrm{Mg}(\mathrm{II}), \mathrm{Cd}(\mathrm{II}), \mathrm{Fe}(\mathrm{III})$, and $\mathrm{Ni}(\mathrm{II})$, which are known to catalyze intramolecular and intermolecular transformations of azirines to ring expansion products, were tried without result.<smiles>N=C1C(=O)CNC1=O</smiles>

68

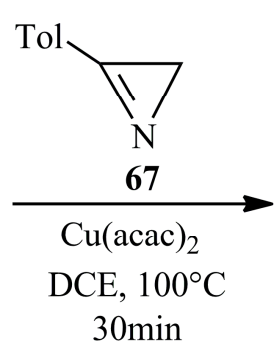

$30 \mathrm{~min}$<smiles>CCCCCCc1cnn([C@]23CC([AlH2])=N[C@]2(O)CNC3=O)n1</smiles>

$66(16 \%)$

Scheme 21. Cu(II)-catalyzed reaction of diazotetramic acid 68 with $2 H$-azirine 67.

Three years later, the same group reported a $\mathrm{Cu}(\mathrm{I})$-catalyzed $(2+3)$ annulation reaction of tetramic acids 69 with $2 \mathrm{H}$-azirine 70 toward hexahydropyrrolo[3,4-b]pyrrole 71 [144]. The reaction 
is catalyzed by $\mathrm{Cu}(\mathrm{II})$ as well, but the best results were obtained with the use of the $N$-heterocyclic carbene-copper(I) complex IPrCuCl (Scheme 22). Inevitably, bis(pyrrolidinedione) was formed as a side product, although the ratio of product to by-product reached 12:1 after optimization.<smiles>[R]C1=C(O)C([R])N([R])C1=O</smiles>

69<smiles>[Y9]C1=NC1[R]</smiles>

70<smiles>[R]C1=N[C@]2(O)C([R])N([R])C(=O)[C@]2([R3])C([R])C1[R]</smiles>

$71(46-91 \%)$<smiles>CCCc1cccc(C(C)C)c1N1C=CN(c2c(C(C)C)cccc2C(C)C)C1Cl</smiles>

$\mathrm{IPrCuCl}$

Scheme 22. NHC-copper(I) complex catalyzed annulation reaction of tetramic acid 69 with $2 H$-azirine 70.

Since then, manganese(II) acetate has been used as a catalyst for the domino annulation reaction of vinyl azide $\mathbf{7 2}$ and 4-hydroxycoumarin $\mathbf{7 3}$ toward tetramic acid analogue spirofuranone-lactam 74 (Scheme 23) [145].

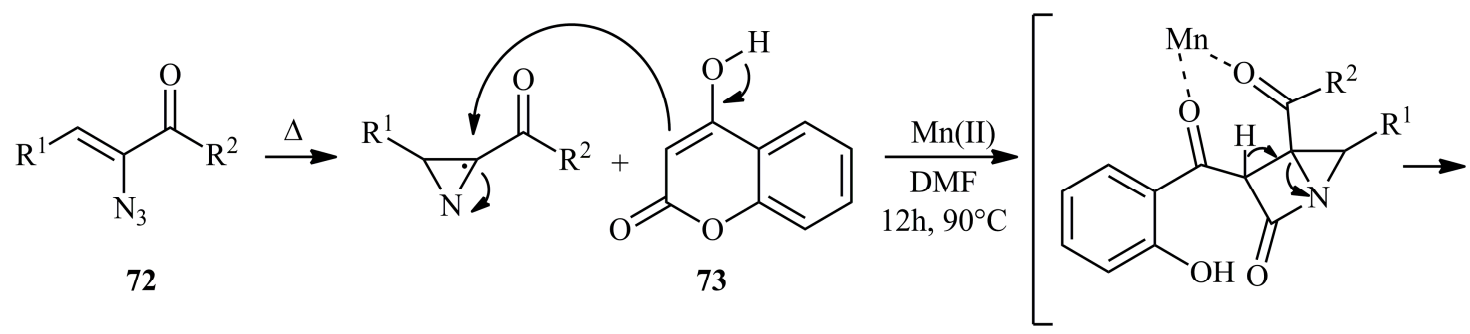

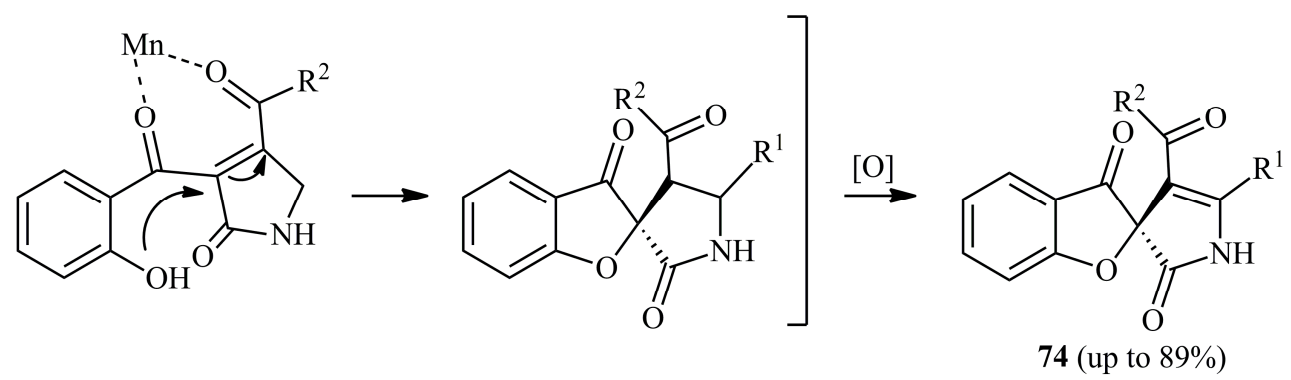

Scheme 23. Proposed mechanism for manganese(II)-catalyzed annulation reaction of vinyl azide 72 and 4-hydroxycoumarin 73.

\subsubsection{Sn(IV)-Catalyzed Diastereoselective Aldol Reaction via Siloxy Pyrroles}

A general diastereoselective aldol method leading to the synthesis of compounds that are commonly found in natural products (e.g., paecilosetin, cylindramide A, and tetrapetalone B) tetramic acid aldolate adduct 75 has been reported by Pettus et al. [146]. The protocol proceeds via C-2 O-silylated pyrrole 76. Tin tetrachloride $\left(\mathrm{SnCl}_{4}\right)$ was found to be the optimal choice among the examined Lewis acids, and the reaction proved to be catalytic (Scheme 24). The authors have examined the incorporation of many aldehydes on 3-methyl, 3-bromo, or 3-unsubstituted tetramic acid 77. 
However, there are no indications of synthesis of 3-acetyl/acyl tetramic acids, or tetramic acids with different substituent on nitrogen.

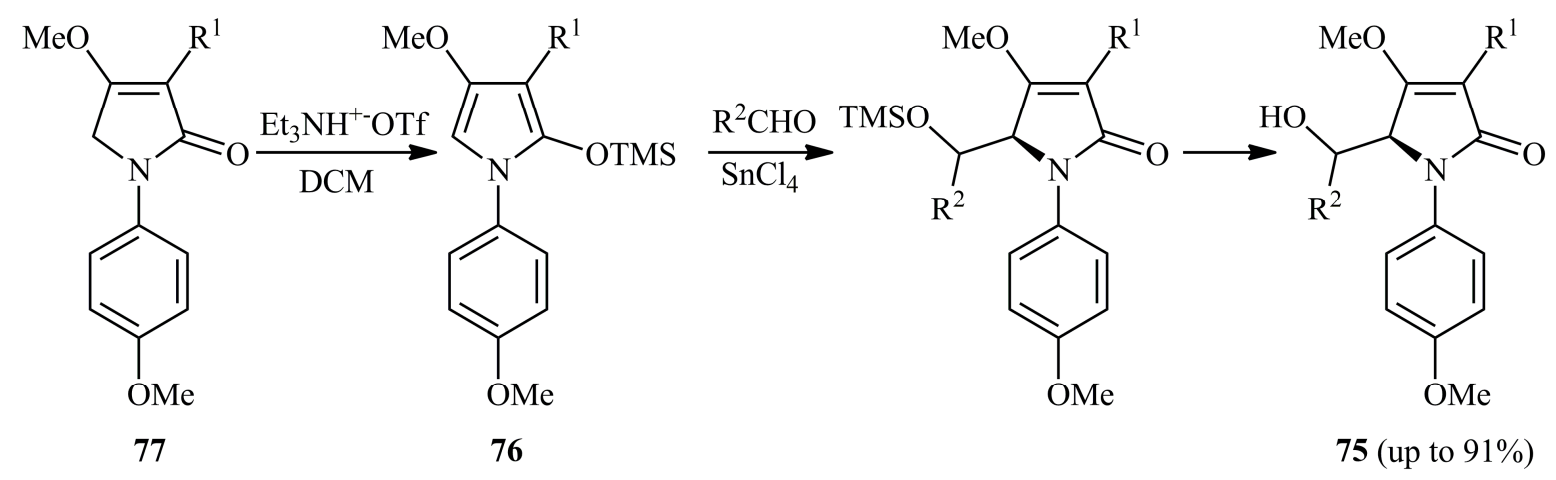

Scheme 24. $\mathrm{SnCl}_{4}$ catalyzed aldol reaction of tetramic acid-derived pyrroles $76\left(\mathrm{R}^{1}=\mathrm{H}, \mathrm{Br}, \mathrm{Me}\right)$.

\section{Conclusions}

The work described in this review represents an effort and advancement in the metal-catalyzed synthesis of tetramic acids. Many reports with new or modified catalytic and other alternative routes have been published recently. Nevertheless, additional work and the development of catalytic systems are needed in order to overcome the conventional methods' drawbacks: harsh conditions and limitations in functionalization.

While application of the developed methods to the total synthesis of natural products is important, the contribution of these methods to the medicinal chemistry is invaluable. Tetramic acids consist of a heterocyclic ring with known antimicrobial, anticancer, and pesticidal activities, and the novel methodologies will give access to more complex or previously inaccessible bioactive structures.

Funding: This work received no external funding.

Acknowledgments: D.M. would like to express sincere gratitude to Olga Igglessi-Markopoulou, National Technical University of Athens and John Markopoulos, National and Kapodistrian University of Athens for the fruitful collaboration on tetramic acids research. The author would like to thank the Greek State Scholarship Foundation and SIEMENS for an IKY Fellowship of Excellence for Postdoctoral Studies in Greece-SIEMENS Program.

Conflicts of Interest: The author declares no conflict of interest.

\section{References}

1. Mo, X.; Li, Q.; Ju, J. Naturally occurring tetramic acid products: Isolation, structure elucidation and biological activity. RSC Adv. 2014, 4, 50566-50593. [CrossRef]

2. Schobert, R.; Schlenk, A. Tetramic and tetronic acids: An update on new derivatives and biological aspects. Bioorg. Med. Chem. 2008, 16, 4203-4221. [CrossRef] [PubMed]

3. Gitterman, C.O. Antitumor, cytotoxic, and antibacterial activities of tenuazonic acid and congeneric tetramic acids. J. Med. Chem. 1965, 8, 483-486. [CrossRef] [PubMed]

4. Jeong, Y.-C.; Anwar, M.; Bikadi, Z.; Hazai, E.; Moloney, M.G. Natural product inspired antibacterial tetramic acid libraries with dual enzyme inhibition. Chem. Sci. 2013, 4, 1008-1015. [CrossRef]

5. Dias, D.; White, J.M.; Urban, S. Pinastric acid revisited: A complete NMR and X-ray structure assignment. Nat. Prod. Res. 2007, 21, 366-376. [CrossRef] [PubMed]

6. Sata, N.U.; Matsunaga, S.; Fusetami, N.; van Soest, R.W.M. Aurantosides D, E, and F: New Antifungal Tetramic Acid Glycosides from the Marine Sponge Siliquariaspongia japonica. J. Nat. Prod. 1999, 62, 969-971. [CrossRef] [PubMed]

7. Sun, Y.L.; Wang, J.; Wang, Y.F.; Zhang, X.Y.; Nong, X.H.; Chen, M.Y.; Xu, X.Y.; Qi, S.H. Cytotoxic and antiviral tetramic acid derivatives from the deep-sea-derived fungus Trichobotrys effuse DFFSCS021. Tetrahedron 2015, 71, 9328-9332. [CrossRef] 
8. Matsunaga, S.; Fusetami, N.; Kato, Y. Aurantosides A and B: Cytotoxic tetramic acid glycosides from the marine sponge Theonella sp. J. Am. Chem. Soc. 1991, 113, 9690-9692. [CrossRef]

9. Li, J.Y.; Strobel, G.; Harper, J.; Lobkovsky, E.; Clardy, J. Cryptocin, a Potent Tetramic Acid Antimycotic from the Endophytic Fungus Cryptosporiopsis cf. quercina. Org. Lett. 2000, 2, 767-770. [CrossRef] [PubMed]

10. Fischer, R.; Voerste, A.; Häuser-Hahn, I.; Lehr, S.; Gatzweiler, E.; Görgens, U.; Heimemann, I. Spiroheterocyclically Substituted Tetramic Acid Derivatives. US Patent US9,809,542, 7 November 2017.

11. Latorse, M.P.; Grosjean-Cournoyer, M.C. Use of Tetramic Acid Derivatives for Controlling Pathogens by Foliar Application. US Patent US20,140,336,233A1, 7 January 2014.

12. Graupner, P.R.; Carr, A.; Clancy, E.; Gilbert, J.; Bailey, K.L.; Derby, J.A.; Gerwick, B.C. The Macrocidins: Novel Cyclic Tetramic Acids with Herbicidal Activity Produced by Phoma macrostoma. J. Nat. Prod. 2003, 66, 1558-1561. [CrossRef]

13. Chen, S.; Qiang, S. Recent advances in tenuazonic acid as a potential herbicide. Pestic. Biochem. Physiol. 2017, 143, 252-257. [CrossRef] [PubMed]

14. Lee, H.R.; Lee, S.C.; Lee, J.E.; Seo, S.M.; Jeong, Y.C.; Jung, C.S.; Moloney, M.G.; Park, I.K. Nematicidal Activity of 3-Acyltetramic Acid Analogues Against PineWood Nematode Bursaphelenchus xylophilus. Molecules 2017, 22, 1568. [CrossRef] [PubMed]

15. Nauen, R.; Reckmann, U.; Thomzik, J.; Thielert, W. Biological profile of spirotetramat (Movento ${ }^{\circledR}$ ) a new two-way systemic (ambimobile) insecticide against sucking pest species. Bayer Cropsci. J. 2008, 61, 245-278.

16. Skylaris, C.-K.; Igglessi-Markopoulou, O.; Detsi, A.; Markopoulos, J. Density functional and ab initio study of the tautomeric forms of 3-acetyl tetronic and 3-acetyl tetramic acids. Chem. Phys. 2003, 293, 355-363. [CrossRef]

17. Steyn, P.S.; Wessels, P.L. Tautomerism in tetramic acids: ${ }^{13} \mathrm{C}$ NMR determination of the structures and ratios of the tautomers in 3-acetyl-5-isopropylpyrrolidine-2,4-dione. Tetrahedron Lett. 1978, 47, 4707-4710. [CrossRef]

18. Nolte, M.J.; Steyn, P.S.; Wessels, P.L. Structural investigations of 3-acylpyrrolidine-2,4-diones by nuclear magnetic resonance spectroscopy and X-ray crystallography. J. Chem. Soc. Perkin Trans. 1 1980, 1057-1065. [CrossRef]

19. Athanasellis, G.; Igglessi-Markopoulou, O.; Markopoulos, J. Tetramic and tetronic acids as scaffolds in bioinorganic and bioorganic chemistry. Bioinorg. Chem. Appl. 2010, 315056. [CrossRef] [PubMed]

20. Zaghouani, M.; Nay, B. 3-Acylated tetramic and tetronic acids as natural metal binders: Myth or reality? Nat. Prod. Rep. 2016, 33, 540-548. [CrossRef] [PubMed]

21. Kaufmann, G.F.; Sartorio, R.; Lee, S.; Rogers, C.J.; Meijler, M.M.; Moss, J.A.; Clapham, B.; Brogan, A.P.; Dickerson, T.J.; Janda, K.D. Revisiting quorum sensing: Discovery of additional chemical and biological functions for 3-oxo-N-acylhomoserine lactones. Proc. Natl. Acad. Sci. USA 2005, 102, 309-314. [CrossRef]

22. Biersack, B.; Diestel, R.; Jagusch, C.; Sasse, F.; Schobert, R. Metal complexes of natural melophlins and their cytotoxic and antibiotic activities. J. Inorg. Biochem. 2009, 103, 72-76. [CrossRef] [PubMed]

23. Matsuo, K.; Kitaguchi, I.; Takata, Y.; Tanaka, K. Structure-Activity Relationships in Tetramic Acids and Their Copper(II) Complexes. Chem. Pharm. Bull. 1980, 28, 2494-2502. [CrossRef] [PubMed]

24. Markopoulou, O.; Markopoulos, J.; Nicholls, D. Synthesis of 3-Butanoyl- and 3-Benzoyl-4-hydroxy-3-pyrrolin2-ones and their Complexes with Metal Ions. J. Inorg. Biochem. 1990, 39, 307-316. [CrossRef]

25. Gavrielatos, E.; Mitsos, C.; Athanasellis, G.; Heaton, B.T.; Steiner, A.; Bickley, J.F.; Igglessi-Markopoulou, O.; Markopoulos, J. Copper(II), cobalt(II), nickel(II) and zinc(II) complexes containing the enolate of $\mathrm{N}$-acetyl-3-butanoyltetramic acid (Habta) and its phenylhydrazone derivative analogues. Crystal structure of $\left[\mathrm{Cu}(\mathrm{abta})_{2}(\mathrm{py})_{2}\right] \cdot 2 \mathrm{H}_{2} \mathrm{O}$. J. Chem. Soc. Dalton Trans. 2001, 639-644. [CrossRef]

26. Matiadis, D.; Igglessi-Markopoulou, O.; McKee, V.; Markopoulos, J. N-acetyl-5-arylidenetetramic acids: Synthesis, X-ray structure elucidation and application to the preparation of zinc (II) and copper (II) complexes. Tetrahedron 2014, 70, 2439-2443. [CrossRef]

27. Matiadis, D.; Tsironis, D.; Stefanou, V.; Elliott, A.G.; Kordatos, K.; Zahariou, G.; Ioannidis, N.; McKee, V.; Panagiotopoulou, A.; Igglessi-Markopoulou, O.; et al. Effect of Metal Complexation on the Antimicrobial Activity of N-Acetyl-3-Acetyl-5-Benzylidene Tetramic Acid: Identification of the Cadmium (II) Complex as Potent Antifungal Agent. J. Inorg. Biochem. under review. 
28. Gavrielatos, E.; Athanasellis, G.; Igglessi-Markopoulou, O.; Markopoulos, J. Cationic diamineplatinum(II) complexes containing the enolate of N,3-acetyl-4-hydroxypyrrolin-2-one. Inorg. Chim. Acta 2003, 344, 128-132. [CrossRef]

29. Gavrielatos, E.; Athanasellis, G.; Heaton, B.T.; Steiner, A.; Bickley, J.F.; Igglessi-Markopoulou, O.; Markopoulos, J. Palladium(II) / $\beta$-diketonate complexes containing the enolates of $N$-acetyl-3-acyltetramic acids: Crystal structure of the Lewis base adduct, $\left[\mathrm{Pd}(\mathrm{py})_{4}\right](\mathrm{abta})_{2}$. Inorg. Chim. Acta 2003, 351, 21-26. [CrossRef]

30. Kawai, H.; Imaoka, T.; Hata, G. Process for the Production of Antitumor Platinum Complexes. PCT International Patent Application WO 9,634,000, 31 October 1996.

31. Hosseini, M.; Kringelum, H.; Murray, A.; Tønder, J.E. Dipeptide Analogues Containing 4-Ethoxy-3-pyrrolin-2-ones. Org. Lett. 2006, 8, 2103-2106. [CrossRef]

32. Hosseini, M.; Grau, J.S.; Sørensen, K.K.; Søtofte, I.; Tanner, D.; Murray, A.; Tønder, J.E. Short and efficient diastereoselective synthesis of pyrrolidinone-containing dipeptide analogues. Org. Biomol. Chem. 2007, 5, 2207-2210. [CrossRef]

33. Hosseini, M.; Tanner, D.; Murray, A.; Tønder, J.E. Pyrrolidinone-modified di- and tripeptides: Highly diastereoselective preparation and investigation of their stability. Org. Biomol. Chem. 2007, 5, 3486-3494. [CrossRef]

34. Raghuraman, A.; Ko, E.; Perez, L.M.; Ioerger, T.R.; Burgess, K. Pyrrolinone-Pyrrolidine Oligomers as Universal Peptidomimetics. J. Am. Chem. Soc. 2011, 133, 12350-12353. [CrossRef] [PubMed]

35. Raghuraman, A.; Xin, D.; Perez, L.M.; Burgess, K. Expanding the Scope of Oligo-pyrrolinone-Pyrrolidines as Protein-Protein Interface Mimics. J. Org. Chem. 2013, 78, 4823-4833. [CrossRef] [PubMed]

36. Cherian, P.T.; Deshpande, A.; Cheramie, M.N.; Bruhn, D.F.; Hurdle, J.G.; Lee, R.E. Design, synthesis and microbiological evaluation of ampicillin-tetramic acid hybrid antibiotics. J. Antibiot. 2017, 70, 65-72. [CrossRef] [PubMed]

37. Cherian, P.T.; Cheramie, M.N.; Marreddy, R.K.R.; Fernando, D.M.; Hurdle, J.G.; Lee, R.E. New $\beta$-lactam-Tetramic acid hybrids show promising antibacterial activities. Bioorg. Med. Chem. Lett. 2018, 28, 3105-3112. [CrossRef] [PubMed]

38. Mulholland, T.P.C.; Foster, R.; Haydock, D.B. Synthesis of pyrrolidine-2,4-diones(tetramic acids) and some derivatives. J. Chem. Soc. Perkin Trans. 1 1972, 2121-2128. [CrossRef]

39. Lacey, R.N. Derivatives of acetoacetic acid. Part VII. $\alpha$-Acetyltetramic acids. J. Chem. Soc. 1954, 850-854. [CrossRef]

40. Royles, B.J.L. Naturally Occurring Tetramic Acids: Structure, Isolation, and Synthesis. Chem. Rev. 1995, 95, 1981-2001. [CrossRef]

41. Schobert, R. Domino syntheses of bioactive tetronic and tetramic acids. Naturwissenschaften 2007, 94, 1-11. [CrossRef] [PubMed]

42. Benary, E. Eine neue Tetronsäure-Synthese. Berichte der Deutschen Chemischen Gesellschaft 1907, 40, $1079-1083$. [CrossRef]

43. Benary, E. Über die Einwirkung von Halogenfettsäure-halogeniden auf Malonester. II. Synthese der Tetramsäure. Berichte der Deutschen Chemischen Gesellschaft 1911, 44, 1759-1765. [CrossRef]

44. Jones, R.C.F.; Sumaria, S. A Synthesis of 3-Acyl-5-alkyl Tetramic Acids. Tetrahedron Lett. 1978, 19, $3173-3176$. [CrossRef]

45. Jones, R.C.F.; Peterson, G.E. Acylation of Pyrrolidine-2,4-diones: Boron Difluoride Complexes of 3-Acyl Tetramic Acids. Tetrahedron Lett. 1983, 24, 4757-4760. [CrossRef]

46. Lee, V.J.; Branfman, A.R.; Herrin, T.R.; Rinehart, K.L. Acyl tetramic acids. 6. Synthesis of 3-dienoyl tetramic acids related to streptolydigin and tirandamycin. J. Am. Chem. Soc. 1978, 100, 4225-4236. [CrossRef]

47. Schlenk, A.; Diestel, R.; Sasse, F.; Schobert, R. A Selective 3-Acylation of Tetramic Acids and the First Synthesis of Ravenic Acid. Chem. Eur. J. 2010, 16, 2599-2604. [CrossRef]

48. Harris, S.A.; Fisher, L.V.; Folkers, K. The Synthesis of Tenuazonic and Congeneric Tetramic Acids. J. Med. Chem. 1965, 8, 478-482. [CrossRef] [PubMed]

49. Isowa, Y.; Ohta, M. Synthesis of Tetramic Acids. Bull. Chem. Soc. Jpn. 1962, 35, 1941-1943. [CrossRef]

50. Boeckman, R.K.; Weidner, C.H.; Perni, R.B.; Napier, J.J. An enantioselective and highly convergent synthesis of (+)-ikarugamycin. J. Am. Chem. Soc. 1989, 111, 8036-8037. [CrossRef] 
51. Paquette, L.A.; Macdonald, D.; Anderson, L.G.; Wright, J. A triply convergent enantioselective total synthesis of (+)-ikarugamycin. J. Am. Chem. Soc. 1989, 111, 8037-8039. [CrossRef]

52. Schlessinger, R.H.; Bebemitz, G.R.; Lin, P.; Poss, A.J. Total synthesis of (-)-tirandamycin A. J. Am. Chem. Soc. 1985, 107, 1777-1778. [CrossRef]

53. Schlessinger, R.H.; Bebemitz, G.R. A versatile 3-acyltetramic acid reagent. J. Org. Chem. 1985, 50, $1344-1346$. [CrossRef]

54. Yoshinari, T.; Ohmori, K.; Schrems, M.G.; Pfaltz, A.; Suzuki, K. Total synthesis and absolute configuration of macrocidin A, a cyclophane tetramic acid natural product. Angew. Chem. Int. Ed. 2010, 49, 881-885. [CrossRef] [PubMed]

55. Hart, A.C.; Phillips, A.J. Total synthesis of (+)-cylindramide A. J. Am. Chem. Soc. 2006, 128, $1094-1095$. [CrossRef] [PubMed]

56. Matthews, J.; Rivero, R.A. Solid-Phase Synthesis of Substituted Tetramic Acids. J. Org. Chem. 1998, 63, 4808-4810. [CrossRef]

57. Ley, S.V.; Smith, S.C.; Woodward, P.R. Use of t-butyl 4-diethylphosphono-3-oxobutanethioate for tetramic acid synthesis: Total synthesis of the plasmodial pigment fuligorubin A. Tetrahedron Lett. 1988, 29, 5829-5832. [CrossRef]

58. Ley, S.V.; Smith, S.C.; Woodward, P.R. Further reactions of t-butyl 3-oxobutanthioate and t-butyl 4-diethyl-phosphono-3-oxobutanthioate: Carbonyl coupling reactions, amination, use in the preparation of 3-acyltetramic acids and application to the total synthesis of fuligorubin A. Tetrahedron 1992, 48, 1145-1174. [CrossRef]

59. Jones, R.C.F.; Tankard, M. A new sequence for the synthesis of 3-(poly)enoyltetramic acids. J. Chem. Soc. Perkin Trans. 1 1991, 240-241. [CrossRef]

60. Jouin, P.; Castro, B.; Nisato, D. Stereospecific synthesis of $N$-protected statine and its analogues via chiral tetramic acid. J. Chem. Soc. Perkin Trans. 1 1987, 1177-1182. [CrossRef]

61. Hamilakis, S.; Kontonassios, D.; Sandris, C. Acylaminoacetyl derivatives of active methylene compounds. 4. J. Heterocycl. Chem. 1996, 33, 825-829. [CrossRef]

62. Jeong, Y.-C.; Moloney, M.G. Tetramic Acids as Scaffolds: Synthesis, Tautomeric and Antibacterial Behaviour. Synlett 2009, 15, 2487-2491. [CrossRef]

63. Liu, Z.; Ruan, X.; Huang, X. A facile solid phase synthesis of tetramic acid. Bioorg. Med. Chem. Lett. 2003, 13, 2505-2507. [CrossRef]

64. Gabriel, S. Einwirkung von Acylamino-säurechloriden auf Natrium-Malon- und -Cyan-essigester. I. Berichte der Deutschen Chemischen Gesellschaft 1913, 46, 1319-1358. [CrossRef]

65. Gabriel, S. Zur Kenntnis der Tetramsäuren. Berichte der Deutschen Chemischen Gesellschaft 1914, 47, $3033-3039$. [CrossRef]

66. Igglessi-Markopoulou, O.; Sandris, C. Acylaminoacetyl derivatives of active methylene compounds. 1. The cyclization of the benzoylaminoacetyl derivatives to $\alpha$-substituted tetramic acids. J. Heterocycl. Chem. 1982, 19, 883-890. [CrossRef]

67. Igglessi-Markopoulou, O.; Sandris, C. Acylaminoacetyl derivatives of active methylene compounds. 2. The cyclization of the acetylaminoacetyl derivatives to $\alpha$-substituted tetramic acids and the formation of $N$-acetyl- $\alpha$-substituted tetramic acids. J. Heterocycl. Chem. 1985, 22, 1599-1606. [CrossRef]

68. Berkley, J.V.; Markopoulos, J.; Markopoulou, O. Synthesis, NMR spectroscopic and X-ray crystallographic studies of N-acetyl-3-butanoyltetramic acid. J. Chem. Soc. Perkin Trans. 2 1994, 1271-1274. [CrossRef]

69. Detsi, A.; Micha-Screttas, M.; Igglessi-Markopoulou, O. Synthesis of N-alkoxycarbonyl-3-substituted tetramic acids and functionalized enols via C-acylation reactions of active methylene compounds with $N$-hydroxysuccinimide esters of N-alkoxycarbonyl- $\alpha$-amino acids. J. Chem. Soc. Perkin Trans. 1 1988, 2443-2450. [CrossRef]

70. Petroliagi, M.; Igglessi-Markopoulou, O. An efficient synthesis of novel N-acetyl-3-alkanoyl and 3-dienoyl tetramic acids. J. Chem. Soc. Perkin Trans. 1 1997, 3543-3548. [CrossRef]

71. Detsi, A.; Igglessi-Markopoulou, O.; Markopoulos, J. Reactions of N-hydroxysuccinimide esters of $\mathrm{N}$-alkoxycarbonyl- $\alpha$-amino acids with active methylene compounds. Synthesis of 3-substituted tetramic acids. Chem. Commun. 1996, 1323-1324. [CrossRef] 
72. Matiadis, D.; Igglessi-Markopoulou, O. Design and Synthesis of Optically Active Esters of $\gamma$-Amino- $\beta$-oxo Acids as Precursors for the Synthesis of Tetramic Acids Derived from L-Serine, L-Tyrosine and L-Threonine. Eur. J. Org. Chem. 2010, 31, 5989-5995. [CrossRef]

73. Athanasellis, G.; Gavrielatos, E.; Igglessi-Markopoulou, O. One-pot synthesis of optically active tetramic acids from amino acids mediated by 1-hydroxybenzotriazole. Synlett 2001, 10, 1653-1655. [CrossRef]

74. Karaiskos, C.S.; Matiadis, D.; Markopoulos, J.; Igglessi-Markopoulou, O. Ruthenium-Catalyzed Selective Hydrogenation of Arylidene Tetramic Acids. Application to the Synthesis of Novel Structurally Diverse Pyrrolidine-2,4-diones. Molecules 2011, 16, 6116-6128. [CrossRef] [PubMed]

75. Prousis, K.C.; Detsi, A.; Igglessi-Markopoulou, O. A Traceless Solid-Phase Approach to Functionalized Tetramic Acids and 2-Amino-4-pyrrolinones. Synlett 2005, 18, 2763-2766. [CrossRef]

76. Schobert, R.; Jagusch, C.; Melanophy, C.; Mullen, G. Synthesis and reactions of polymer-bound $\mathrm{Ph}_{3} \mathrm{P}=\mathrm{C}=\mathrm{C}=$ O: A quick route to tenuazonic acid and other optically pure 5-substituted tetramates. Org. Biomol. Chem. 2004, 2, 3524-3529. [CrossRef] [PubMed]

77. Schobert, R.; Jagusch, C. An expedient synthesis of 3-acyltetramic acids of the melophlin family from $\alpha$-aminoesters and immobilized $\mathrm{Ph}_{3}$ PCCO. Tetrahedron 2005, 61, 2301-2307. [CrossRef]

78. Schobert, R. Preparation of (Triphenylphosphoranylidene)-Ketene from (Methoxycarbonylmethylene)Triphenylphosphorane. Org. Synth. 2005, 82, 140-146. [CrossRef]

79. Schobert, R.; Jagusch, C. Solid-phase domino syntheses of functionalized tetronates with $\mathrm{Ph}_{3} \mathrm{P}=\mathrm{C}=\mathrm{C}=\mathrm{O}$. Tetrahedron Lett. 2003, 44, 6449-6451. [CrossRef]

80. Löffler, J.; Schobert, R. Domino syntheses of five-, six-and seven-membered $\mathrm{O}-, \mathrm{N}$-and $\mathrm{S}$-heterocycles from $\alpha-, \beta$-and $\gamma$-substituted carboxylic esters. J. Chem. Soc. Perkin Trans. 1 1996, 2799-2802. [CrossRef]

81. Schobert, R.; Müller, S.; Bestmann, H.-J. One-pot Synthesis of $\alpha, \gamma$-Disubstituted Tetronic Acids from $\alpha$-Hydroxyallyl Esters: A Novel Tandem-Wittig-Claisen-Reaction. Synlett 1995, 5, 425-426. [CrossRef]

82. Schobert, R.; Siegfried, S.; Nieuwenhuyzen, M.; Milius, W.; Hampel, F. Selective C-acylation of CH-active dicarbonyl compounds with ketenylidenetriphenylphosphorane: Syntheses and structures of 3-phosphoranylideneacyltetronic acids, 3-phosphoranylideneacyl-4-oxocoumarins, and 4-phosphoranylideneacylpyrazol-5-ones. J. Chem. Soc. Perkin Trans. 1 2000, 1723-1730. [CrossRef]

83. Schobert, R.; Dietrich, M.; Mullen, G.; Urbina-Gonzales, J.-M. Phosphorus ylide based functionalizations of tetronic and tetramic acids. Synthesis 2006, 22, 3902-3914. [CrossRef]

84. Kempf, K.; Schmitt, F.; Bilitewski, U.; Schobert, R. Synthesis, stereochemical assignment, and bioactivity of the Penicillium metabolites penicillenols B1 and B2. Tetrahedron 2015, 71, 5064-5068. [CrossRef]

85. Winterer, M.; Kempf, K.; Schobert, R. Synthesis of an Isomer of the Decalinoyltetramic Acid Methiosetin by a Stereocontrolled IMDA Reaction of a Metal-Chelated 3-Trienoyltetramate. J. Org. Chem. 2016, 81, 7336-7341. [CrossRef] [PubMed]

86. DeShong, P.; Cipollina, J.A.; Lowmaster, N.K. A general method for the synthesis of tetramic acid derivatives. J. Org. Chem. 1988, 53, 1356-1364. [CrossRef]

87. DeShong, P.; Lowmaster, N.K.; Baralt, O. Methodology for the synthesis of 3-acyltetramic acids. J. Org. Chem. 1983, 48, 1149-1150. [CrossRef]

88. Prousis, K.C.; Markopoulos, J.; McKee, V.; Igglessi-Markopoulou, O. Efficient construction of functionalized 5-carboxymethyl tetramic acids using $N$-Ac-L-aspartic anhydride as chiral building block. Tetrahedron 2010, 66, 3944-3950. [CrossRef]

89. Mitsos, C.A.; Zografos, A.L.; Igglessi-Markopoulou, O. Regioselective ring opening of malic acid anhydrides by carbon nucleophiles. Application in the synthesis of chiral tetronic acids. J. Org. Chem. 2000, 65, 5852-5853. [CrossRef] [PubMed]

90. Stachel, H.-D.; Harigel, K.K.; Poschenrieder, H.; Burghard, H. Die umsetzung von azlactonen mit CH-aciden verbindungen. 2. Mitteil. J. Heterocycl. Chem. 1980, 17, 1195-1199. [CrossRef]

91. Fehrentz, J.; Bourdel, E.; Califano, J.; Chaloin, O.; Devin, C.; Garrouste, P.; Lima-Leite, A.; Llinares, M.; Rieunieur, F.; Vizavonna, J.; et al. Synthesis of chiral urethane $N$-alkoxycarbonyl tetramic acids from urethane N-carboxyanhydrides (UNCAs). Tetrahedron Lett. 1994, 35, 1557-1560. [CrossRef]

92. Jones, R.C.F.; Patience, J.M. A new pyrone strategy for the synthesis of 3-acyltetramic acids. Tetrahedron Lett. 1989, 30, 3217-3218. [CrossRef]

93. Jones, R.C.F.; Bhalay, G.; Carter, P.A.; Duller, K.A.M.; Vulto, S.I.E. A cycloaddition approach to 3-acyltetramic and 3-acyltetronic acids. J. Chem. Soc. Perkin Trans. 1 1994, 2513-2515. [CrossRef] 
94. Andrews, M.D.; Brewster, A.; Moloney, M.G. A concise approach to functionalised, homochiral tetramic acids. Tetrahedron Asymm. 1994, 5, 1477-1478. [CrossRef]

95. Andrews, M.D.; Brewster, A.G.; Crapnell, K.M.; Ibbett, A.J.; Jones, T.; Moloney, M.G.; Prout, K.; Watkin, D. Regioselective Dieckmann cyclisations leading to enantiopure highly functionalised tetramic acid derivatives. J. Chem. Soc. Perkin Trans. 1 1998, 223-235. [CrossRef]

96. Jeong, Y.-C.; Anwar, M.; Nguyen, T.N.; Tan, B.S.W.; Chai, C.L.L.; Moloney, M.G. Control of chemoselectivity in Dieckmann ring closures leading to tetramic acids. Org. Biomol. Chem. 2011, 9, 6663-6669. [CrossRef] [PubMed]

97. Anwar, M.; Moloney, M.G. Efficient enantioselective synthesis of tetramic acids and lactams from threonine. Tetrahedron Lett. 2007, 48, 7259-7262. [CrossRef]

98. Anwar, M.; Cowley, A.R.; Moloney, M.G. Novel chiral pyrrolidinone scaffolds derived from threonine with antibacterial activity. Tetrahedron Asymm. 2010, 21, 1758-1770. [CrossRef]

99. Holloway, C.A.; Matthews, C.J.; Jeong, Y.-C.; Moloney, M.G.; Roberts, C.F.; Yaqoob, M. Novel Chiral Skeletons for Drug Discovery: Antibacterial Tetramic Acids. Chem. Biol. Drug Des. 2011, 78, 229-235. [CrossRef] [PubMed]

100. Jeong, Y.-C.; Moloney, M.G. Synthesis and antibacterial activity of monocyclic 3-carboxamide tetramic acids. Beilstein J. Org. Chem. 2013, 9, 1899-1906. [CrossRef] [PubMed]

101. Jeong, Y.-C.; Bikadi, Z.; Hazai, E.; Moloney, M.G. A Detailed Study of Antibacterial 3-Acyltetramic Acids and 3-Acylpiperidine-2,4-diones. ChemMedChem 2014, 9, 1826-1837. [CrossRef]

102. Ishida, T.; Kobayashi, R.; Yamada, T. Novel Method of Tetramic Acid Synthesis: Silver-Catalyzed Carbon Dioxide Incorporation into Propargylic Amine and Intramolecular Rearrangement. Org. Lett. 2014, 16, 2430-2433. [CrossRef]

103. Ishida, T.; Kikuchi, S.; Tsubo, T.; Yamada, T. Silver-Catalyzed Incorporation of Carbon Dioxide into o-Alkynylaniline Derivatives. Org. Lett. 2013, 15, 848-851. [CrossRef]

104. Ishida, T.; Kikuchi, S.; Yamada, T. Efficient Preparation of 4-Hydroxyquinolin-2(1H)-one Derivatives with Silver-Catalyzed Carbon Dioxide Incorporation and Intramolecular Rearrangement. Org. Lett. 2013, 15, 3710-3713. [CrossRef] [PubMed]

105. Yoshida, S.; Fukui, K.; Kikuchi, S.; Yamada, T. Silver-catalyzed Preparation of Oxazolidinones from Carbon Dioxide and Propargylic Amines. Chem. Lett. 2009, 38, 786-787. [CrossRef]

106. Song, Q.-W.; Chen, W.-Q.; Ma, R.; Yu, A.; Li, Q.-Y.; Cheng, Y.; He, L.-N. Bifunctional Silver(I) Complex-Catalyzed $\mathrm{CO}_{2}$ Conversion at Ambient Conditions: Synthesis of a-Methylene Cyclic Carbonates and Derivatives. ChemSusChem 2015, 8, 821-827. [CrossRef] [PubMed]

107. Arshadi, S.; Vessally, E.; Sobati, M.; Hosseinian, A.; Behradnia, A. Chemical fixation of $\mathrm{CO}_{2}$ to $\mathrm{N}$-propargylamines: A straightforward route to 2-oxazolidinones. J. $\mathrm{CO}_{2}$ Util. 2017, 19, 120-129. [CrossRef]

108. Hu, J.; Ma, J.; Zhang, Z.; Zhu, Q.; Zhou, H.; Lu, W.; Han, B. A route to convert $\mathrm{CO}_{2}$ : Synthesis of 3,4,5-trisubstituted oxazolones. Green Chem. 2015, 17, 1219-1225. [CrossRef]

109. Xu, C.-P.; Huang, P.-Q.; Py, S. SmI 2 -Mediated Coupling of Nitrones and tert-Butanesulfinyl Imines with Allenoates: Synthesis of $\beta$-Methylenyl- $\gamma$-lactams and Tetramic Acids. Org. Lett. 2012, 14, 2034-2037. [CrossRef]

110. Bai, W.-J.; Jackson, S.K.; Pettus, T.R.R. Mild Construction of 3-Methyl Tetramic Acids Enabling a Formal Synthesis of Palau'imide. Org. Lett. 2012, 14, 3862-3865. [CrossRef]

111. Takahashi, K.; Midori, M.; Kawano, K.; Ishihara, J.; Hatakeyama, S. Entry to Heterocycles Based on Indium-Catalyzed Conia-Ene Reactions: Asymmetric Synthesis of (-)-Salinosporamide A. Angew. Chem. Int. Ed. 2008, 47, 6244-6246. [CrossRef]

112. Scott, M.E.; Schwarz, C.A.; Lautens, M. Synthesis of $\alpha, \gamma$-Unsaturated Lactams via a Magnesium Iodide Promoted Ring Expansion of Secondary Methylenecyclopropyl Amides. Org. Lett. 2006, 8, 5521-5524. [CrossRef]

113. Clough, J.M.; Pattenden, G.; Wight, P.G. Radical cyclisations of propargyl bromoamides and propargyl bromoesters. New routes to tetramic acids, pyrrolinones, tetronic acids and butenolides. Tetrahedron Lett. 1989, 30, 7469-7472. [CrossRef]

114. Bennett, N.; Prodger, J.C.; Pattenden, G. A synthesis of a common intermediate to the lactone-pyrrolidinone ring systems in oxazolomycin A and neooxazolomycin. Tetrahedron 2007, 63, 6216-6231. [CrossRef] 
115. Brennan, C.J.; Pattenden, G.; Rescourio, G. Formal synthesis of (+)-lactacystin based on a novel radical cyclisation of an $\alpha$-ethynyl substituted serine. Tetrahedron Lett. 2003, 44, 8757-8760. [CrossRef]

116. Pettenden, G.; Rescourio, G. A new synthetic approach to (+)-lactacystin based on radical cyclisation of enantiopure $\alpha$-ethynyl substituted serine derivatives to 4-methylenepyrrolidinones. Org. Biomol. Chem. 2008, 6, 3428-3438. [CrossRef] [PubMed]

117. Namy, J.L.; Girard, P.; Kagan, H.B. A new preparation of some divalent lanthanide iodides and their usefulness in organic synthesis. New J. Chem. 1977, 1, 5-7. [CrossRef]

118. Nicolaou, K.C.; Ellery, S.P.; Chen, J.S. Samarium Diiodide Mediated Reactions in Total Synthesis. Angew. Chem. Int. Ed. 2009, 48, 7140-7165. [CrossRef]

119. Gabriele, B.; Plastina, P.; Salerno, G.; Costa, M. A New Synthesis of 4-Dialkylamino-1,5-dihydropyrrol-2-ones by Pd-Catalyzed Oxidative Aminocarbonylation of 2-Ynylamines. Synlett 2005, 6, 935-938. [CrossRef]

120. Gabriele, B.; Salerno, G.; Plastina, P.; Costa, M.; Crispini, A. Expedient Synthesis of 4-Dialkylamino-5H-furan-2-ones by One-Pot Sequential Pd-Catalyzed Oxidative Carbonylation of 2-Yn-1-ols-Conjugate Addition-Lactonization. Adv. Synth. Catal. 2004, 346, 351-358. [CrossRef]

121. Imada, Y.; Yuasa, M.; Nakamura, I.; Murahashi, S. Copper(I)-Catalyzed Amination of Propargyl Esters. Selective Synthesis of Propargylamines, 1-Alken-3-ylamines, and (Z)-Allylamines. J. Org. Chem. 1994, 59, 2282-2284. [CrossRef]

122. Dittmer, D.C.; Avilov, D.V.; Kandula, V.S.; Purzycki, M.T.; Martens, Z.J.; Hohn, E.B.; Bacler, M.W. Tetramic acids and derivatives by telluride-triggered Dieckmann cyclizations. ARKIVOC 2010, 6, 61-83. [CrossRef]

123. Wunder, A.; Schobert, R. An expeditious synthesis of the ascomycete metabolite rigidiusculamide B. Org. Biomol. Chem. 2016, 14, 9262-9266. [CrossRef] [PubMed]

124. Clive, D.L.J.; Anderson, P.C.; Moss, N.; Singh, A. New method for coupling allylic halides: Use of telluride ${ }^{2-}$ ion species. J. Org. Chem. 1982, 47, 1641-1647. [CrossRef]

125. Dittmer, D.C.; Li, Q.; Avilov, D.V. Synthesis of Coumarins, 4-Hydroxycoumarins, and 4-Hydroxyquinolinones by Tellurium-Triggered Cyclizations. J. Org. Chem. 2005, 70, 4682-4686. [CrossRef] [PubMed]

126. Dos Santos, A.A.; Princival, J.L.; Comasseto, J.V.; de Barros, S.M.G.; Brainer Neto, J.E. Tellurium/lithium exchange reactions in the synthesis of spiroketals and 1,6-dioxygenated systems. Tetrahedron 2007, 63, 5167-5172. [CrossRef]

127. Engman, L. Synthetic applications of organotellurium chemistry. Acc. Chem. Res. 1985, 18, $274-279$. [CrossRef]

128. Cossy, J.; Belotti, D.; Cuong, N.K.; Chassagnard, C. Photoreductive cyclization of N,N-dialkyl- $\beta$-oxoamides: Synthesis of piperidines and $\delta$-lactams. Tetrahedron 1993, 49, 7691-7700. [CrossRef]

129. Feng, X.; Wang, J.-J.; Xun, Z.; Zhang, J.-J.; Huang, Z.-B.; Shi, D.-Q. Highly selective synthesis of functionalized polyhydroisoquinoline derivatives via a three-component domino reaction. Chem. Commun. 2015, 51, 1528-1531. [CrossRef] [PubMed]

130. Feng, X.; Wang, J.-J.; Zhang, J.-J.; Cao, C.-P.; Huang, Z.-B.; Shi, D.-Q. Regioselective synthesis of functionalized $[1,8]$ naphthyridine derivatives via three-component domino reaction under catalyst-free conditions. Green Chem. 2015, 17, 973-981. [CrossRef]

131. Iida, T.; Hori, K.; Nomura, K.; Yoshii, E. A New Entry to 5-Unsubstituted 3-Acyltetramic Acids from Aldehydes. Heterocycles 1994, 38, 1839-1844. [CrossRef]

132. García-Aranda, M.I.; García-López, M.T.; Pérez de Vega, M.J.; González-Muñiz, R. Tetramic acids and indole derivatives from amino acid $\beta$-keto esters. Fine-tuning the conditions of the key $\mathrm{Cu}$-catalyzed reaction. Tetrahedron Lett. 2014, 55, 2142-2145. [CrossRef]

133. Xie, X.; Cai, G.; Ma, D. CuI/l-Proline-Catalyzed Coupling Reactions of Aryl Halides with Activated Methylene Compounds. Org. Lett. 2005, 7, 4693-4695. [CrossRef]

134. Storgaard, M.; Dörwald, F.Z.; Peschke, B.; Tanner, D. Palladium-Catalyzed $\alpha$-Arylation of Tetramic Acids. J. Org. Chem. 2009, 74, 5032-5040. [CrossRef] [PubMed]

135. Larsen, S.; Bernstein, J. Geometrical Isomerism of 2,4-Dibenzylidene-3-phenyl-5-oxazolidones. Their Rearrangement to 1, 4-Diphenyl-2-benzylidene-3,5-pyrrolidiones. J. Am. Chem. Soc. 1950, 72, 4447-4452. [CrossRef]

136. Jones, R.C.F.; Begley, M.J.; Peterson, G.E.; Sumaria, S. Acylation of pyrrolidine-2,4-diones: A synthesis of 3-acyltetramic acids. X-ray molecular structure of 3-[1-(difluoroboryloxy)ethylidene]-5-isopropyl-1-methylpyrrolidine-2,4-dione. J. Chem. Soc. Perkin Trans. 1 1990, 1959-1968. [CrossRef] 
137. Marquardt, U.; Schmid, D.; Jung, G. Racemic Synthesis of the New Antibiotic Tetramic Acid Reutericyclin. Synlett 2000, 8, 1131-1132. [CrossRef]

138. Tunik, S.P.; Pilyugina, T.S.; Koshevoy, I.O.; Selivanov, S.I.; Haukka, M.; Pakkanen, T.A. Reaction of (S)-BINAP with $\mathrm{H}_{4} \mathrm{Ru}_{4}(\mathrm{CO})_{12}$. The First Example of Face-Bridging BINAP Coordination and $100 \%$ Stereoselectivity in Formation of a Chiral Tetranuclear Cluster Framework. Organometallics 2004, 23, 568-579. [CrossRef]

139. Stachel, H.-D.; Poschenrieder, H.; Redlin, J.; Schachtner, J.; Zeitler, K. Reduktone von Tetron-, Thiotetron- und Tetramsäuren, II. Reduktone durch Rhodium-katalysierte Zersetzung von Diazoverbindungen. Liebigs Ann. Chem. 1994, 129-132. [CrossRef]

140. Stachel, H.-D.; Poschenrieder, H.; Redlin, J. Thermolyse und Photolyse von cyclischen Diazoverbindungen. Z. Naturforsch. 1996, 51b, 1325-1333. [CrossRef]

141. Poschenrieder, H.; Höfner, G.; Stachel, H.-D. 5-Arylidene-3-aryl-pyrrolidine-2,4-diones with Affinity to the N-Methyl-D-aspartate (Glycine Site) Receptor, Part I. Arch. Pharm. Pharm. Med. Chem. 1998, 331, 389-394. [CrossRef]

142. Poschenrieder, H.; Stachel, H.-D. Reduktone von Maleinimiden. Arch. Pharm. 1989, 322, 301-302. [CrossRef]

143. Rostovskii, N.V.; Novikov, M.S.; Khlebnikov, A.F.; Korneev, S.M.; Yufit, D.S. Cu(II)-Catalyzed domino reaction of $2 \mathrm{H}$-azirines with diazotetramic and diazotetronic acids. Synthesis of 2-substituted 2H-1,2,3-triazoles. Org. Biomol. Chem. 2013, 11, 5535-5545. [CrossRef]

144. Rostovskii, N.V.; Sakharov, P.A.; Novikov, M.S.; Khlebnikov, A.F.; Starova, G.L. Cu(I)-NHC-Catalyzed $(2+3)$-Annulation of Tetramic Acids with $2 H$-Azirines: Stereoselective Synthesis of Functionalized Hexahydropyrrolo[3,4-b]pyrroles. Org. Lett. 2015, 17, 4148-4151. [CrossRef] [PubMed]

145. Guo, S.; Chen, B.; Zhao, D.; Chen, W.; Zhang, G. Manganese(II)-Mediated Domino Annulation Reaction of Vinyl Azides and 4-Hydroxycoumarin: A Stereoselective Synthesis of Spirobenzofuranone-lactams. Adv. Synth. Catal. 2016, 358, 3010-3014. [CrossRef]

146. David, J.G.; Bai, W.-J.; Weaver, M.G.; Pettus, T.R.R. A General Diastereoselective Catalytic Vinylogous Aldol Reaction Among Tetramic Acid-Derived Pyrroles. Org. Lett. 2014, 16, 4384-4387. [CrossRef] [PubMed]

(C) 2019 by the author. Licensee MDPI, Basel, Switzerland. This article is an open access article distributed under the terms and conditions of the Creative Commons Attribution (CC BY) license (http:/ / creativecommons.org/licenses/by/4.0/). 